Review

\title{
Current Status and Challenges Associated with CNS-Targeted Gene Delivery across the BBB
}

\author{
Seigo Kimura ${ }^{1,2, *}$ and Hideyoshi Harashima ${ }^{1,2}$ \\ 1 Laboratory for Molecular Design of Pharmaceutics, Faculty of Pharmaceutical Sciences, \\ Hokkaido University, Sapporo 060-0812, Japan; harasima@pharm.hokudai.ac.jp \\ 2 Laboratory of Innovative Nanomedicine, Faculty of Pharmaceutical Sciences, Hokkaido University, \\ Sapporo 060-0812, Japan \\ * Correspondence: seigo757@eis.hokudai.ac.jp
}

Received: 8 October 2020; Accepted: 11 December 2020; Published: 15 December 2020

\begin{abstract}
The era of the aging society has arrived, and this is accompanied by an increase in the absolute numbers of patients with neurological disorders, such as Alzheimer's disease (AD) and Parkinson's disease (PD). Such neurological disorders are serious costly diseases that have a significant impact on society, both globally and socially. Gene therapy has great promise for the treatment of neurological disorders, but only a few gene therapy drugs are currently available. Delivery to the brain is the biggest hurdle in developing new drugs for the central nervous system (CNS) diseases and this is especially true in the case of gene delivery. Nanotechnologies such as viral and non-viral vectors allow efficient brain-targeted gene delivery systems to be created. The purpose of this review is to provide a comprehensive review of the current status of the development of successful drug delivery to the CNS for the treatment of CNS-related disorders especially by gene therapy. We mainly address three aspects of this situation: (1) blood-brain barrier (BBB) functions; (2) adeno-associated viral (AAV) vectors, currently the most advanced gene delivery vector; (3) non-viral brain targeting by non-invasive methods.
\end{abstract}

Keywords: Gene therapy; BBB; AAV; non-viral vectors; non-invasive delivery; neurological disorders

\section{Introduction}

The aging of society has now arrived, and this has been accompanied by an increase in the absolute numbers of patients of neurological disorders, such as Alzheimer's disease (AD) and Parkinson's disease (PD) and this increase is global in nature [1]. Neurological disorders show the highest disabilityadjusted life years (DALYs) and are the second leading cause of death. Neurological disorders, especially AD and other forms of dementia, affect not only the patients themselves, but also the people around them such as their families and caregivers. As a result, such diseases are thought to have a larger social burden compared to other diseases. The most critical points in the current situation is that there is no effective treatment despite the fact that the number of patients increase with the aging of the population. Based on a questionnaire survey for physicians in Japan, one of the countries with the most rapidly aging population, neurological disorders are recognized as diseases/symptoms for which the development of novel treatment methods and drugs are urgently required [2]. According to a recent report, neurological disorders have low levels of both drug contribution and treatment satisfaction, and the development of new drugs would be highly desirable (Figures 1 and 2).

The bottleneck in drug development for CNS diseases is the absence of effective drug delivery system (DDS) technology for delivering the therapeutic agents into the brain [3]. Less than $1 \%$ of the dose of most systemically administered compounds and drugs actually reach the brain. It may not be possible to efficiently deliver a drug to a human disease site, and the expected efficacy and 
safety may not be obtained, even if a candidate compound that would be expected to be effective at the non-clinical level can be identified. For example, it is thought that trastuzumab is effective for the treatment of a brain tumor since the brain tumor that has spread from a HER2-positive breast cancer into the brain remains HER2-positive. However, since the antibody trastuzumab cannot be efficiently delivered to the brain, it becomes difficult to actually use it for therapy [4]. Thus, even if there are drugs that would be expected to show theoretical effects, a DDS technology that meets those expectations does not currently exist, and the development of therapeutic agents for CNS may not progress. In other words, if a drug could be delivered to the brain using a DDS approach, it may have the potential to dramatically improve the prognosis of diseases in the brain.

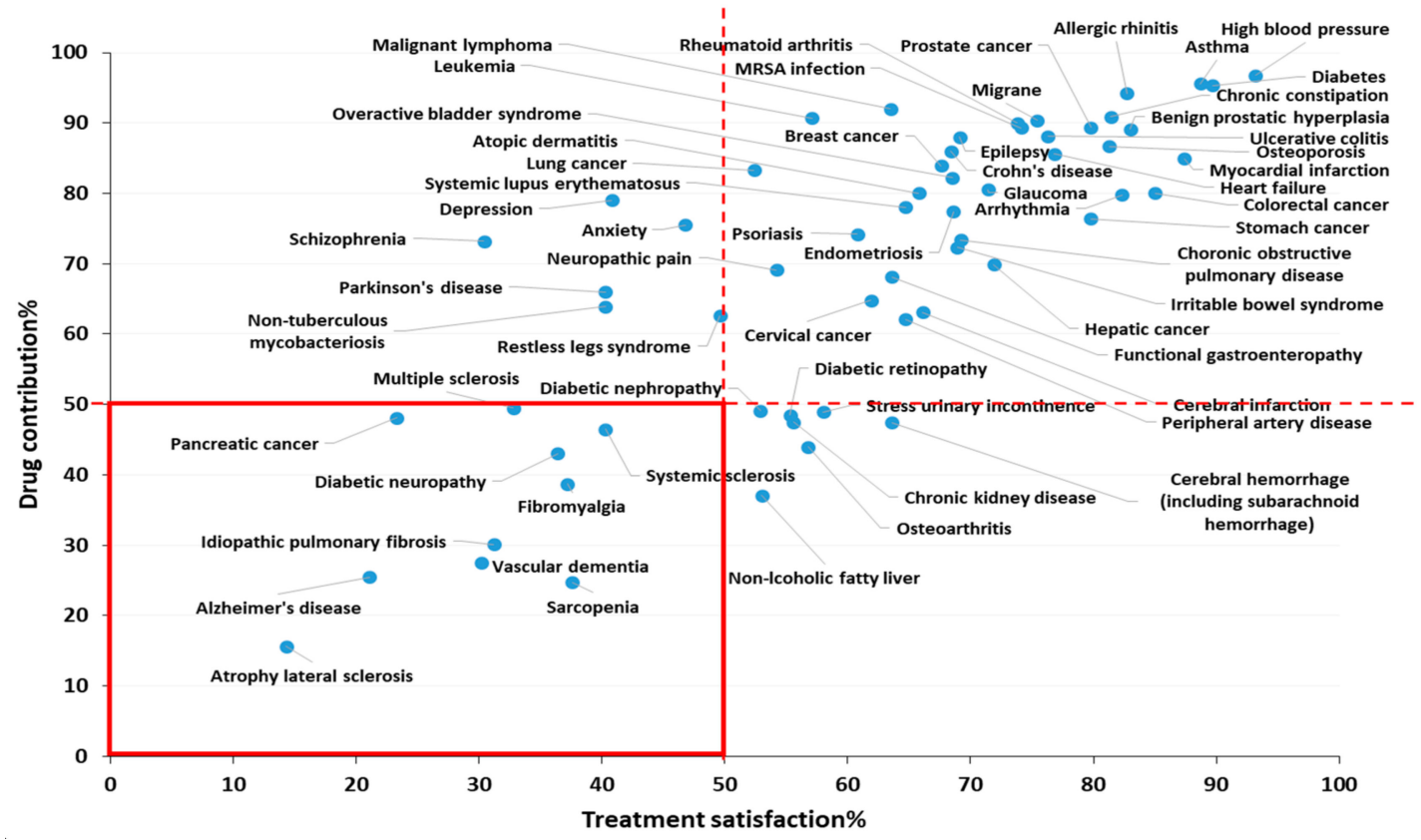

Figure 1. Treatment satisfaction and drug contribution. This figure is based on a medical need survey concerning medical satisfaction and drug contribution for physicians in Japan (2014 2019). Treatment satisfaction\% was defined as the percentage of physicians who chose "Fully satisfied" and "Satisfied to some extent" from four options (1. Fully satisfied; 2. Satisfied to some extent; 3. Dissatisfied; 4. Not being treated) for the disease in the questionnaire. Drug contribution\% was defined as the percentage of respondents who chose "Fully contributed" and "Contributed to some extent" of the four options (1. Fully contributed; 2 . Contributed to some extent; 3 . Not contributed; 4 . No effective drugs) for each disease in questionnaire. This 2-axis dot plot based on a Japan questionnaire survey for physicians indicates the requirement of developing new drugs for the treatment of neurological disorders. There are 10 diseases with less than $50 \%$ of both treatment satisfaction and drug contribution, and 4 of them are neurological disorders including atrophy lateral sclerosis (ALS), Alzheimer's disease (AD), multiple sclerosis (MS), and vascular dementia, figure is adopted with permission from [2], Japan Health Sciences Foundation, 2019.

Actually, there is a drug, (Spinraza), that is used for the clinical treatment of Spinal Muscular Atrophy (SMA) [5]. Spinraza is an antisense oligonucleotide (ASO)-based drug, which induces the expression of the functional survival motor neuron (SMN) protein from the SMN2 gene by exon inclusion. The efficacy and safety of the drug was confirmed in a randomized double-blind parallel-group comparison study of infants with SMA. However, it should be noted that the safe and reliable administration of this drug involves intrathecal administration. In the case of SMA in infants, many patients develop scoliosis due to disease progression, and it is necessary to consider the use of ultrasonic imaging for the correct intrathecal injection, which means that there are technical difficulties associated with this type of treatment [6]. Moreover, Spinraza needs to be administered every four 
months for infant SMA patients and every six months for non-infant SMA, and there are concerns regarding the risk for infections and tissue damage with each administration [7]. Given the complexity of this, highly invasive intrathecal administration, a DDS technology that can efficiently deliver drugs to the CNS disease site by a relatively low-invasive administration method such as intravenous injection would provide medical care with much less physical burden on the patients.

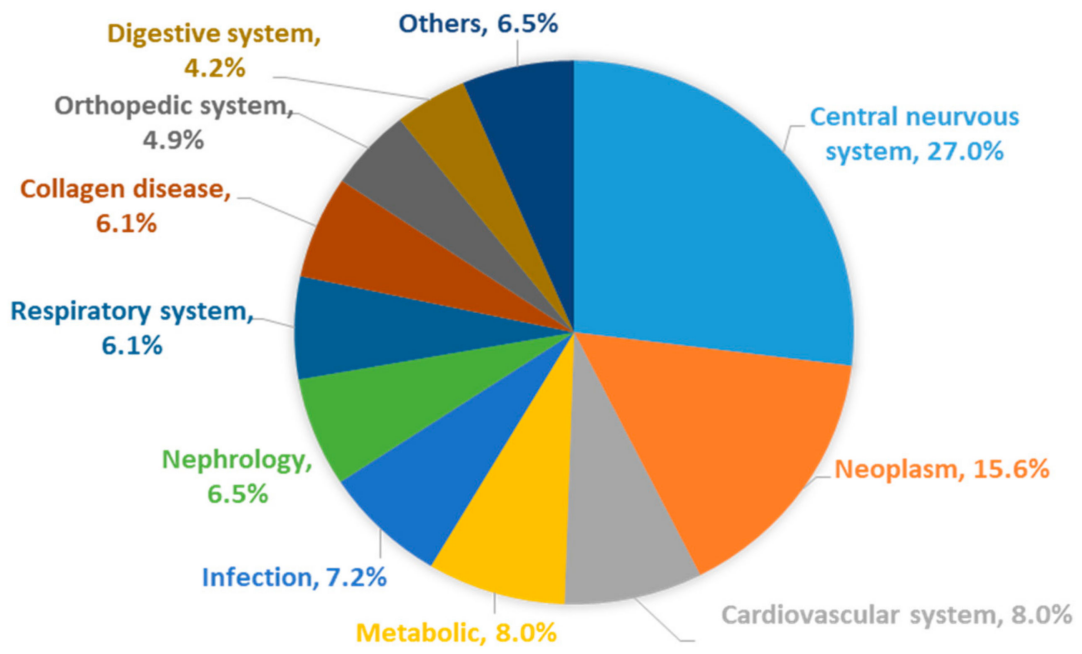

Figure 2. Diseases where there is an urgent need to develop new treatments and drugs. The pie chart is the result of a questionnaire concerning diseases that require the development of new drugs in Japan, figure is adopted with permission from [2], Japan Health Sciences Foundation, 2019. This figure was based on data from survey participants that were asked to list three diseases that they considered to be in urgently in need of new treatments and therapeutics, and then categorized those diseases into central nervous system (CNS), neoplasm, cardiovascular system, metabolic, etc. The result shows the diseases in most need of new drug development are CNS disorders.

Gene therapy is currently a subject of great interest since it represents one of the most promising medicines for treating diseases that are currently incurable with conventional medicines [8-10]. In fact, gene therapy drug approval has been progressing at an increasing pace since 2012, as shown in Table 1. The concept of gene therapy originated in the 1970s, and in 1990, the first clinical trial involving the use of gene therapy was conducted for treating an adenosine deaminase (ADA) deficiency. However, the clinical trials failed to unequivocally show a clear efficacy, and in 1995, the Orkin-Motulsky Report from the National Institute of Health (NIH) appeared, noting the need to focus on basic research. The Gelsingner case in 1999 (death from adenovirus-induced systemic inflammatory response syndrome) and leukemia caused by a chromosomal insertion mutation of a retrovirus vector were reported, and gene therapy entered a period of stagnation. Since 2008, however, gene therapy development has been rekindled with the development of improved vectors, and gene therapy has now become a more active area of research [10]. Although most gene therapies involve local administration or ex vivo gene transfer (Table 1), the advent of Zolgensma confirmed that in vivo targeted gene therapy is a clear possibility and is expected to further accelerate the development of DDS technology in anticipation of gene therapy. In addition, gene therapy has emerged as having potential for the treatment of CNS diseases in the past decade [11-15]. Gene therapy strategies and therapeutic effects for CNS diseases that have been demonstrated are summarized in Table 2. The main gene therapy strategies involve the replacement of defective/dysfunctional genes and silencing mutant genes. In PD, which is characterized by loss of dopaminergic neurons in the substantia nigra and a decrease in dopamine levels in the striatum, the transfer of genes that encode for several enzymes such as aromatic L-amino acid decarboxylase (AADC) that converts L-dopa to dopamine [16], glutamic acid decarboxylase (GAD) that modulates production of the neurotransmitter GABA ( $\gamma$-aminobutyric acid) are all possibilities [17]. In AD treatment, the main strategy is to remove extracellular amyloid 
since amyloid deposition is thought to be central event in $\mathrm{AD}$ [18]. It has been reported that an apolipoprotein $\mathrm{E}$ (APOE) isoform influences the risk for AD, and APOE4 is known to be a strong genetic risk factor [19]. APOE4 increases brain amyloid- $\beta(A \beta)$ pathology relative to other APOE isoforms, and the absence of APOE is protective [20]. Other reports have also shown that APOE secreted by the glia stimulates neuronal $\mathrm{A} \beta$ production with an APOE $4>$ APOE $3>$ APOE2 potency rank order [21]. It has been reported that $A \beta$ production is suppressed by attenuating $\beta$ cleavage and promoting $\alpha$ cleavage by editing amyloid precursor protein (APP), which is a precursor protein of $\mathrm{A} \beta$, with CRISPR-Cas9 [22]. The polyglutamine binding protein 1 (PQBP1) that is a major regulator of synapse-related proteins has been identified as an alternate target to amyloid deposition for AD treatment [23]. However, most of the gene vectors used in the above reports are administered by invasive local injection, and such brain targeting continues to be a challenge, although Zolgensma, an intravenously administered gene therapy for SMA, was approved in 2019 [24,25]. As mentioned above, an invasive local injection to CNS sites have a high risk. In addition, DDS technology is much more important in cases of nucleic acid-based medicines, such as gene therapy, due to their lower stability in the body compared to other conventional medicines, such as small molecule drugs and antibody drugs. Therefore, delivery to the brain is the biggest hurdle in developing new drugs for the treatment of CNS diseases, especially in the case of nucleic acid-based medicines.

Table 1. Gene therapy products launched around the world.

\begin{tabular}{|c|c|c|c|c|c|}
\hline Product (Company) & Vector & Delivery Gene & Target Disease & $\begin{array}{c}\text { Approved } \\
\text { Country (Year) }\end{array}$ & Reference \\
\hline $\begin{array}{l}\text { Gendicine (Shenzhen } \\
\text { SiBiono GeneTech, } \\
\text { Shenzhen, China) }\end{array}$ & $\begin{array}{l}\text { Adenovirus } \\
\text { (in vivo, IT) }\end{array}$ & $\begin{array}{l}\text { Human wild-type } \\
\text { p53 }\end{array}$ & $\begin{array}{l}\text { Head and neck } \\
\text { squamous cell } \\
\text { carcinoma }\end{array}$ & China (2003) & \\
\hline $\begin{array}{l}\text { Oncorine (Shanghai } \\
\text { Sunway Biotech, } \\
\text { Shanghai, China) }\end{array}$ & $\begin{array}{l}\text { Oncolytic } \\
\text { adenovirus } \\
\text { (in vivo, IT) }\end{array}$ & & $\begin{array}{l}\text { Head and neck } \\
\text { cancer }\end{array}$ & China (2006) & {$[26]$} \\
\hline $\begin{array}{c}\text { Rexin G (Epeius } \\
\text { Biotechnology, } \\
\text { Monrovia, CA, USA) }\end{array}$ & $\begin{array}{l}\text { Retrovirus } \\
\text { (in vivo, IV) }\end{array}$ & Mutant cyclin G1 & $\begin{array}{l}\text { Chemoresistant } \\
\text { solid tumor }\end{array}$ & $\begin{array}{l}\text { Philippines } \\
\text { (2007) }\end{array}$ & \\
\hline $\begin{array}{l}\text { Neovagulgen (Human } \\
\text { Stem Cell Institute, } \\
\text { Moscow, Russia) }\end{array}$ & $\begin{array}{c}\text { Plasmid } \\
\text { (in vivo, IM) }\end{array}$ & $\begin{array}{c}\text { Vascular } \\
\text { endothelial growth } \\
\text { factor (VEGF) }\end{array}$ & $\begin{array}{c}\text { Peripheral artery } \\
\text { disease }\end{array}$ & $\begin{array}{l}\text { Russia (2011) } \\
\text { Ukraine (2013) }\end{array}$ & \\
\hline $\begin{array}{c}\text { Glybera (Uniqure, } \\
\text { Amsterdam, } \\
\text { Netherlands) } \\
\text { Discontinued }\end{array}$ & $\begin{array}{c}\text { AAV1 } \\
\text { (in vivo IM) }\end{array}$ & Lipoprotein lipase & $\begin{array}{c}\text { Lipoprotein lipase } \\
\text { deficiency }\end{array}$ & Europe (2012) & [27] \\
\hline $\begin{array}{c}\text { Imlygic (Amgen, } \\
\text { Thousand Oaks, CA, } \\
\text { USA) }\end{array}$ & $\begin{array}{l}\text { Oncolytic HSV1 } \\
\text { (in vivo, IT) }\end{array}$ & $\begin{array}{c}\text { Granulocyte } \\
\text { macrophage } \\
\text { colony-stimulating } \\
\text { factor (GM-CSF) }\end{array}$ & $\begin{array}{l}\text { Malignant } \\
\text { melanoma }\end{array}$ & $\begin{array}{l}\text { America (2015) } \\
\text { Europe (2015) }\end{array}$ & [28] \\
\hline $\begin{array}{l}\text { Strimveils (GSK, } \\
\text { Brentford, United } \\
\text { Kingdam) }\end{array}$ & $\begin{array}{l}\text { Retrovirus } \\
\text { (ex vivo) }\end{array}$ & $\begin{array}{c}\text { Adenosine } \\
\text { deaminase (ADA) }\end{array}$ & ADA deficiency & Europe (2016) & [29] \\
\hline $\begin{array}{l}\text { Zalmoxis (MolMed } \\
\text { S.p.A, Milano, Italy) }\end{array}$ & $\begin{array}{l}\text { Retrovirus } \\
\text { (ex vivo) }\end{array}$ & $\begin{array}{c}\text { Herpesvirus } \\
\text { thymidine kinase }\end{array}$ & $\begin{array}{c}\text { Graft versus host } \\
\text { disease }\end{array}$ & Europe (2016) & \\
\hline $\begin{array}{l}\text { Kymriah (Novartis, } \\
\text { Basel, Switzerland) }\end{array}$ & $\begin{array}{l}\text { Retrovirus } \\
\text { (ex vivo) }\end{array}$ & $\begin{array}{l}\text { Chimeric antigen } \\
\text { receptor (CAR) } \\
\text { against CD19 }\end{array}$ & $\begin{array}{c}\text { Acute } \\
\text { lymphoblastic } \\
\text { leukemia }\end{array}$ & $\begin{array}{l}\text { America (2017) } \\
\text { Europe (2018) } \\
\text { Japan (2019) }\end{array}$ & [30] \\
\hline $\begin{array}{c}\text { Yescarta (Kite Pharma, } \\
\text { Santa Monica, CA, } \\
\text { USA) }\end{array}$ & $\begin{array}{l}\text { Retrovirus } \\
\text { (ex vivo) }\end{array}$ & CAR against CD19 & $\begin{array}{l}\text { Large B cell } \\
\text { lymphoma }\end{array}$ & $\begin{array}{l}\text { America (2017) } \\
\text { Europe (2018) }\end{array}$ & [31] \\
\hline $\begin{array}{c}\text { Luxturna (Spark } \\
\text { Therapeutics, } \\
\text { Philadelphia, PA, USA) }\end{array}$ & $\begin{array}{c}\text { AAV2 } \\
\text { (in vivo, SR) }\end{array}$ & RPE65 & Retinal dystrophy & $\begin{array}{l}\text { America (2017) } \\
\text { Europe (2018) }\end{array}$ & \\
\hline
\end{tabular}


Table 1. Cont.

\begin{tabular}{cccccc}
\hline Product (Company) & Vector & Delivery Gene & Target Disease & $\begin{array}{c}\text { Approved } \\
\text { Country (Year) }\end{array}$ & Reference \\
\hline $\begin{array}{c}\text { Zynteglo (Bluebird Bio, } \\
\text { Cambridge, MA, USA) }\end{array}$ & $\begin{array}{c}\text { Lentivirus } \\
\text { (ex vivo) }\end{array}$ & Beta-globin & Beta thalassemia & Europe (2019) & {$[32]$} \\
\hline $\begin{array}{c}\text { Zolgensma (Novartis, } \\
\text { Basel, Switzerland) }\end{array}$ & $\begin{array}{c}\text { AAV9 } \\
\text { (in vivo, IV) }\end{array}$ & SMN1 & $\begin{array}{c}\text { Spinal mascular } \\
\text { atrophy (SMA) }\end{array}$ & $\begin{array}{c}\text { America (2019) } \\
\text { Europe (2019) }\end{array}$ & {$[25]$} \\
\hline $\begin{array}{c}\text { Collategene } \\
\text { (Mitsubishi Tanabe }\end{array}$ & $\begin{array}{c}\text { Plasmid } \\
\text { Pharma Corporation, } \\
\text { Osaka, Japan) }\end{array}$ & HGF & $\begin{array}{c}\text { Critical limb } \\
\text { ischemia }\end{array}$ & Japan (2019) \\
\hline
\end{tabular}

IT: intra-tumor, IV: intravenous, IM: intra-muscular, SR: sub-retinal.

Table 2. Gene therapy strategies and therapeutic effects for major CNS diseases.

\begin{tabular}{cccc}
\hline Disease & Target Gene (Protein) & Mechanism & Reference \\
\hline \multirow{3}{*}{ PD } & AADC & Replace & {$[16]$} \\
\cline { 2 - 4 } & GAD & Replace & {$[17]$} \\
\cline { 2 - 4 } & GBA1 & Replace & {$[33]$} \\
\hline \multirow{nyyy}{*}{ AD } & SNCA & Silence & {$[34]$} \\
\cline { 2 - 4 } & APOE4 & Silence/immunotherapy & {$[20]$} \\
\cline { 2 - 4 } & APP (amyloid-beta) & Replace & {$[35]$} \\
\cline { 2 - 4 } & MAPT (tau) & Silence & {$[22]$} \\
\hline \multirow{nyyy}{*}{ ALS } & PQBP1 & Replace & {$[36]$} \\
\hline & SOD1 & Silence & {$[23]$} \\
\hline SMA & C9orf72 & Silence & {$[37]$} \\
\hline & TARDBP & Silence & {$[38]$} \\
\hline & SMN1 & Replace & {$[24]$} \\
\hline
\end{tabular}

The blood-brain barrier (BBB) is the biggest limiting hurdle to drug delivery to the brain in the case of the use of systemically injected vectors [3]. The BBB is a barrier that prevents several circulating molecules including harmful agents from entering the brain, and controlling the proper balance of nutrients. In terms of drug delivery to the brain, a rational strategy is taking advantage of innate BBB functions such as BBB receptors/transporters that promote substance transfer into the brain [40-42]. Several nanoparticles (NPs) designed for receptor mediated transcytosis have been reported; transferrin (Tf) receptor [43-47], nicotinic receptor [48-50], low density lipoprotein receptor (LDLR) [51-55], glucose transporter (GLUT) [56,57]. Although the usefulness of those receptor mediated strategies have been demonstrated, we need to consider BBB functions and pathologies because there are differences in BBB structures between the normal brain and the diseased brain [58-60]. Based on the above, an understanding of the mechanisms of BBB transport and BBB features in normal and pathological conditions is needed. Thus, we discuss BBB transporters, mechanisms of BBB crossing, and BBB breakdown in pathological conditions in this review.

Gene delivery vectors are mainly classified into two types, viral and non-viral vectors. Viral vectors have been demonstrated to have a 10 times to 1000 times higher efficiency of gene transfer in comparison to non-viral vectors [61-63]. Due to the high transfection efficiency of these vectors, viral vectors have been used in many clinical trials in gene therapy [8]. There are several types of viral vectors available for gene delivery [64], and among these, adeno-associated virus (AAV)-vectors have been widely used in many studies related to gene therapy [65-67] due to its features such as the potential of gene transfer to non-dividing/differentiated cells, long-term expression, relatively weak immunogenicity, 
and especially their applicability to in vivo gene delivery (tissue tropism) compared to other viral vectors. Additionally, AAV-vectors are particularly heavily used to transduce the therapeutic genes to CNS site for the treatment of neurodegenerative disorders [12,65]. Actually, the AAV9 serotype is used as a vector in gene therapy for the treatment of SMA, Zolgensma, as mentioned above. CNS-targeted AAV serotypes and Zolgensma are discussed in later sections. However, viral vectors have several demerits such as high immunogenicity, small carrying capacity of therapeutic genes, difficulties associated with scale-up preparation, and high costs. In terms of these points, non-viral vectors offer some advantages in spite of their low transfection efficiency compared to viral vectors [68]. Various types of non-viral vectors have been studied and developed in attempts to increase efficiency from the viewpoint of controlling biodistribution and the intracellular trafficking of the vectors [69-74]. Several synthetic vectors are available for gene delivery. One strategy depends on using therapeutic nucleic acids that are conjugated with different functional devices such as peptides, polymers, sugars, proteins, antibodies or aptamers [75]. Another strategy depends on encapsulating the nucleic acids in nanoparticles (NPs) in which the size can be tuned [76]. Conjugated systems are small in size and can easily be eliminated from the body by renal clearance. Furthermore, the nucleic acids in the conjugates are not protected and must be chemically modified to resist degradation in the circulation. On the other hand, NP systems are sufficiently large that renal clearance can be avoided and can provide more protection for the nucleic acids in the circulation. The NPs used for gene delivery can be broadly classified to polymeric and lipid nanoparticles (LNPs). In 2018, the first approved LNP-based RNA interference (RNAi) therapeutic, OnpattroTM (Patisiran) for the treatment of hereditary transthyretin-mediated amyloidosis (hTTAR amyloidosis), has opened the era of nucleic acid nanomedicines [77]. This breakthrough in the field of non-viral gene delivery received substantial interest worldwide and clearly pointed out the importance of non-viral systems such as LNPs for developing more approved drugs in the future. Additionally, there are also reports regarding non-viral brain-targeted systems, and we will introduce them and discuss the strategies for brain targeting focusing on systemically injected systems.

In this review, we provide a comprehensive insight into the developments of successful drug delivery to the CNS for the treatment of CNS disorders by gene therapy.

\section{BBB Function}

In this section, we briefly mention the general literature regarding BBB characteristics, because understanding the anatomical and physiological features and functions of the BBB is essential for designing rational brain-targeted systems. There are four parts in the section; (A) General structure of the BBB, in which we introduce the cell types that make up the BBB, (B) Transporters expressed on the $\mathrm{BBB}$, mainly we focus on receptors and transporters that are likely to be used for nanoparticle delivery, (C) Mechanism of BBB crossing, this part outlines the BBB penetration mechanism reported in immune cells and AAV vectors, (D) BBB breakdown under pathological conditions, we also need to consider the differences in BBB structure and function between normal conditions and diseased conditions, we discuss how they are different.

\subsection{General Structure of the $B B B$}

The $B B B$ is the interface that regulates transport between the circulation and neural tissue. The structural basis of the BBB is provided by the endothelial lining of the brain microvasculature. The brain microvascular endothelial cells are specialized cells that differ from peripheral capillaries: no fenestration, decreased pinocytosis and transcytosis, tight inter-endothelial junctions (TJs), high expression and asymmetric localization of transporters and high metabolic activity [78-82]. The development and maintenance of BBB function is dependent upon the concerted interaction of multiple cell types with the brain capillary endothelium, namely: astrocytes, pericytes, microglia and neurons (Figure 3). Astrocytes are star-shaped glial cells that constitute a large portion of brain cells and the glia is not homogenously distributed in the brain $[83,84]$. Their main functions are to supply 
neurons with nutrients and to regulate synaptic activities [85]. In addition, astrocytic end-feet cover almost the entire BBB endothelium [86], and modulate the availability of certain nutrients to the brain and the expression of the receptors/transporters that recognize these nutrients $[79,87,88]$. In addition, they can also change the BBB permeability through the modulation of TJs and efflux pumps [89,90]. Pericytes play an important role in stabilizing blood vessels and maintaining their function. They are present around micro blood vessels, and the ratio of vascular endothelial cells to pericytes differs depending on the specific organ (Ex. endothelial-to-pericyte ratio; human skeletal muscle (100:1), CNS (1:1 3:1) [86,91-93]). It has also been reported that pericyte density and coverage are correlated with endothelial barrier properties, endothelial cell turnover which means "large coverage = less turnover", and orthostatic blood pressure $[93,94]$. Pericytes are able to modulate BBB integrity (increase of transendothelial electrical resistance (TEER)), transcytosis rate, and the expression of efflux pumps $[95,96]$. Microglia act as the resident immune cells of the brain, and play a role in the innate immune response in the CNS [97]. They have different morphologies depending on the activation state, and under different physiological conditions [98]. Microglia has a double-edged sword in brain pathologies, which means that they survey the influx of blood-born components into the CNS to protect the brain under normal condition, but, on the other hand, their dysregulation has been implicated in the initiation and progression of neurological disorders [98,99]. Moreover, microglia contribute to BBB integrity by exerting dual effects on BBB permeability, the initial protection of the BBB integrity but microglia develop into a phagocytic phenotype to increase BBB permeability as inflammation progresses [100]. These different cell types establish the BBB structure and function via interactions between each other.

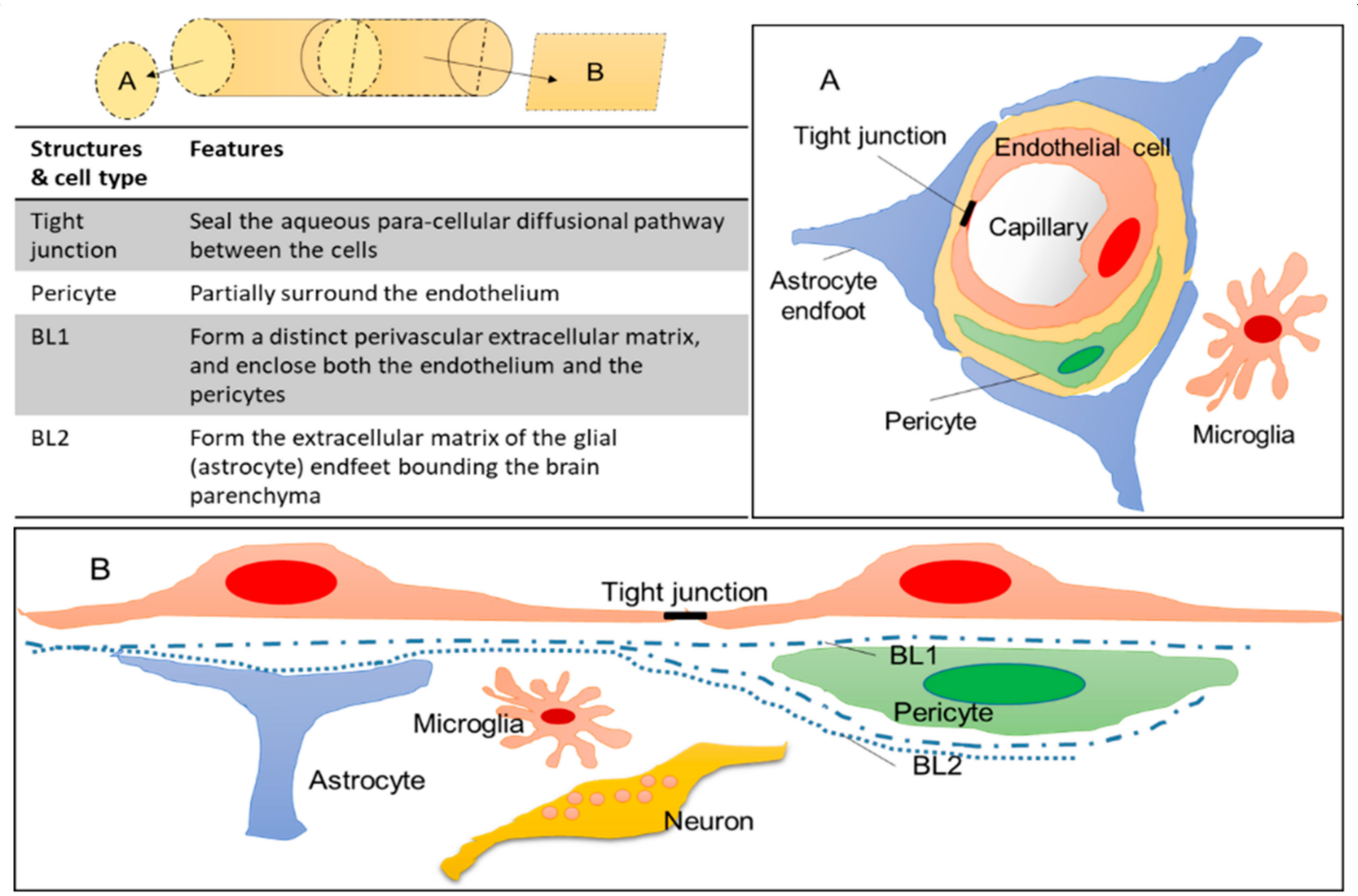

Figure 3. General structure of the BBB. Figure 3A,B show different cross-sectional views of brain blood vessels, respectively. The upper left picture shows the direction of cross-section of (A) (cut in round slices) and (B) (cut into squares) when the brain blood vessels are viewed as a cylinder. BL; basal lamina.

\subsection{Transporters Expressed on the $B B B$}

Despite the fact that the BBB is a tight physiological barrier, vital molecules such as nutrients, neurotransmitters, and amino acids can cross the barrier to enter the brain. The specific receptors and transporters that are expressed on the BBB make this possible [58,101]. Brain endothelial transport systems regulate molecular exchanges between blood-and-brain and brain-and-blood. These BBB 
receptors/transporters have been validated by transcriptomics and/or proteomics [95,102-112]. Rational brain targeted DDS is based on the understanding of drug and/or carrier interactions with those BBB receptors/transporters. As shown in Figure 4, the main internalization pathways carried on by receptors/transporters that are expressed on the BBB include transporter-mediated pathway, clathrin-dependent pathway, and caveolae-dependent pathway. Once internalized, depending on the internalization pathway and/or the type of vesicles, it undergoes different intracellular routes, such that it can interact with other cellular compartments or vesicles such as endosomes, lysosomes and exocytose. This section reviews representative receptors/transporters in the above three internalization pathways, and discusses the pros and cons of each in terms of BBB crossing.

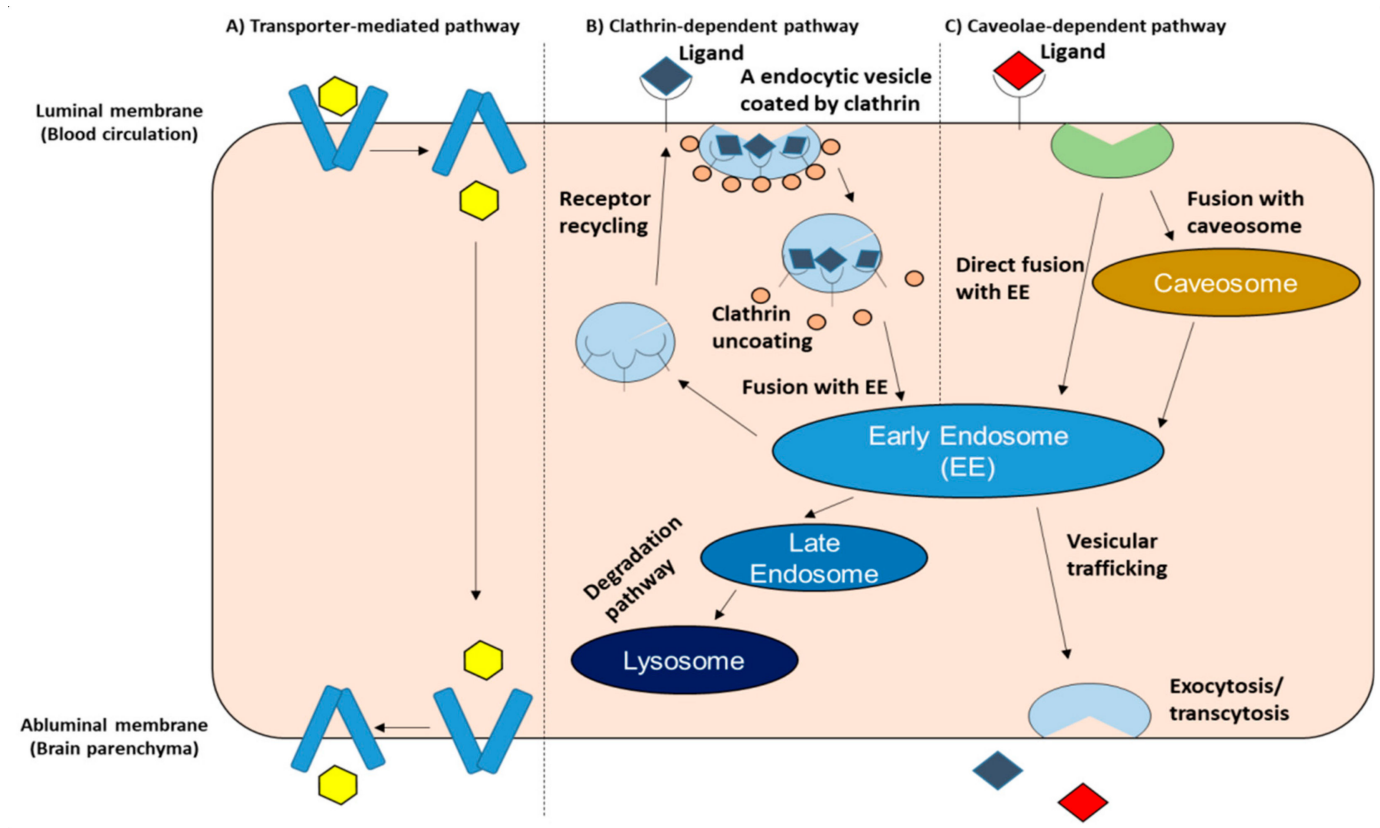

Figure 4. Main internalization pathways for receptors/transporters expressed on the BBB. (A) Transportermediated pathway: This pathway implies only an interaction between the ligand and the receptor. Conformation change is induced after ligand binding; (B) Clathrin-dependent pathway: This pathway requires the association of specific endocytic proteins, promoting the formation of clathrin-coated vesicles. The vesicles then dissociate from the membrane and undergo $\mathrm{pH}$ changes which promote the dissociation of clathrin and the ligand/receptor complex. The receptor is recycled; $(C)$ The caveolae-dependent pathway: This pathway is regulated by the caveolin- 1 and cavin proteins. The caveolae-dependent pathway has the ability to bypass lysosomal storage, which is different from the clathrin-dependent pathway. Little precise information if available regarding the BBB transcytosis mechanism, which is referred to as "Vesicular trafficking" in the figure, despite several reports indicating that transcytosis is regulated by Rab GTPases, which are a known group of molecules that control intracellular vesicle transport [82]. EE-Early Endosome.

First, we introduce glucose transporters (GLUTs) as a representative of transporter-mediated transcytosis. GLUTs play a role of the transport of glucose and/or other hexose/pentose sugars from the blood into the cell. GLUTs are expressed throughout the body, and there are various GLUT family members that have variable expression levels depending on the site where they are located. The most abundant GLUT is GLUT1, which is expressed in red blood cells and endothelial cells with a high glycosylation rate $(55 \mathrm{kDa})$, and in astrocytes, neurons and microglia with a low glycosylation rate (45 kDa). GLUT3 is the main transporter expressed on neurons. GLUT5, the major GLUT in microglia, transports fructose and has a low affinity for glucose [113]. GLUTs are expressed at both the luminal and abluminal sides of BBB endothelial cells for regulating brain glucose levels. GLUTs are transporters and not receptors, so the internalization pathway is a process that involves conformation change after ligand binding, and the release of the ligand into the cell (Figure 4). However, this process may 
differ in the case of nanoparticles due to their nanometric size. It appears that the particles attach to the transporter and enter the cell with the recycling of the transporter. In hypoglycemic animals, the total GLUT1 of micro-vessel protein and luminal GLUT1 are increased [114]. GLUT1 on the cell membrane undergoes endocytosis and is pooled in intracellular vesicles $[115,116]$. The above reports suggest that the dynamic intracellular recycling of GLUT1 occurs in response to changes in blood glucose level. Actually, it has been reported that the recycling of GLUT1 improves the translocation of nanocarriers to the brain [56]. The authors used glycaemic control in order to boost the crossing of glucosylated nanocarriers of the BBB into the brain. As mentioned above, some strategies such as the use of recycling of transporters should be considered for allow nanoparticles to cross the BBB through transporter-mediated pathways.

Second, we describe the transferrin receptor (TfR) as a representative of clathrin-dependent transcytosis. TfR is one of the most extensively studied and exploited receptor that is expressed on the BBB [117]. A high expression level of TfR at the BBB makes them one of the most desirable receptors for drug delivery across the BBB [43-45,47,117,118], although it is also expressed in other tissues throughout the body [119]. Two types of TfR have been reported, TfR1 and TfR2 [120]. TfR2 is mostly expressed by erythroid cell lines, normal erythroid cells at various stages of differentiation, and leukemia and pre-leukemia cells [121]. Although the differences between TfR1 and TfR2 are not fully understood, it has been reported that the TfR-mediated transferrin-bound iron uptake is mediated primarily via TfR1 but not TfR2 in HuH7 human hepatoma cells [122]. In addition, it was recently reported that TfR2 facilitates iron transport from lysosomes to mitochondria in erythroblasts and dopaminergic neurons, and defects in the TfR2 can cause systemic iron overload, hemochromatosis [123]. TfR1 is highly expressed at the luminal side of the BBB, and promotes the uptake of iron by the brain by binding to transferrin saturated with iron [124]. This process involves receptor-mediated transcytosis (RMT) through clathrin-dependent transcytosis and involves the formation of an endosome (Figure 4). After acidification of the lumen of the endosome, the binding affinity between the TfR complex and iron become weaker, resulting in its dissociation. The transferrin and TfR are then recycled back to the cell surface [125]. There are several limitations of TfR1 as a targeted receptor for crossing the BBB: (1) its expression throughout the whole body can lead to non-specific targeting; (2) competition between endogenous transferrin and the targeting ligand that binds to TfR1 can reduce targeting efficiency [126]; (3) the inability of TfR transcytosis to occur through brain capillary endothelial cells to the abluminal membrane and brain parenchyma [127,128]. In a recent report [128], the use of TfR-targeting was found to increase the binding between immuno-liposomes and brain capillary endothelial cells, however, the transcytosis of immuno-liposomes was not evident. Namely, such a targeting approach might increase the uptake of nanoparticles at the BBB several fold but might not lead to BBB transport. In order to overcome the above limitations, the use of monoclonal antibodies (mAbs) has been suggested [128-130]. One such example is OX26 mAb [119,128]. OX26, a mAb for the specific targeting of rat TfR, binds to an allosteric site on TfR that is distinct from the transferrin binding site, and does not interfere with Tf binding [131,132].

Third, we use a low-density lipoprotein receptor (LDLR) as an example of caveolae-dependent transcytosis. The LDLR at the BBB plays a role in controlling the homeostasis of cholesterol, thus acting as a mediator for the internalization of cholesterol-rich low-density lipoproteins (LDL), apolipoprotein B and E. The process occurs at the BBB, although it is significantly greater at the liver [133]. Recognizing apolipoproteins promotes endocytosis via a caveolae-dependent mechanism. This pathway is different from the clathrin-dependent pathway due to the fact that caveosomes do not deliver their cargo to lysosomes [134,135]. This feature is advantageous in terms of the intracellular trafficking of therapeutic genes. There are two main strategies for targeting LDLR; (1) protein corona-mediated targeting; (2) ligand-based targeting. Once nanoparticles are injected into the systemic circulation, nanoparticles encounter serum components, such as proteins, resulting in the formation of a protein corona on the surface. The formation of a protein corona is critical for the design of efficient and safe nanoparticles for tissue-targeting, nanomedicines, and other applications, so research related 
to the protein corona is a subject of great interest [136-146]. Although protein corona formation on a nanoparticle surface may adversely affect targeting [147], controlling them can also be applied to achieve more effective targeting [51,54,55,148-154]. With regard to the brain targeting through LDLR-mediated transcytosis, it was proposed that the use of certain apolipoproteins, such as ApoE and ApoA1, would be useful as endogenous ligands for crossing the BBB. One such example is polysorbate- 80 coated nanoparticles which bind to ApoE and interact with the LDLR, resulting in an increased brain accumulation compared to nanoparticles without ApoE binding or with low levels of ApoE binding [51,155-157]. Below, we also describe the brain targeting strategies that involve a protein corona. Angiopeps, which were derived from the Kunitz domains of aprotinin and other human proteins [158], is known as the most extensively explored ligand for targeting LDLRs for BBB crossing. Angiopep-2, one of the family of angiopeps, exhibited a particularly higher transcytosis capacity and parenchymal accumulation compared to transferrin, lactoferrin, and avidin, of which BBB transport is mediated by low-density lipoprotein receptor-related protein-1 (LRP1) [159]. In fact, angiopep-2 could act as a ligand for LRP in the delivery of drug-loaded nanoparticles [158-164]. The use of angiopep-2-conjugated PEG-PCL nanoparticles showed LRP-mediated transcytosis and the system could target glioma cells in vivo after intravenous injection [164]. A biodistribution study using nanoparticles labeled with near-infrared fluorophore also showed that angiopep- 2 functionalized nanoparticles were mainly localized in the striatum, hippocampus, and cerebellum in the brain [160]. Furthermore, angiopep-conjugated dendrigraft poly-L-lysine nanoparticles were used for gene delivery to produce neuroprotective effects in a chronic PD model [163]. In that report, angiopep-conjugated nanoparticles exhibited a higher uptake and gene expression in the brain compared to unmodified nanoparticles, and nanoparticles containing human glial cell line-derived neurotrophic factor gene showed an improved locomotor activity and the apparent recovery of dopaminergic neurons compared to other control groups. Although not a gene delivery sytem, angiopep-2 has been used in clinical trials for the delivery of small molecule drugs to the brain for the treatment of brain metastases (BM) [165-167]. ANG1005, consists of three paclitaxel molecules that are covalently linked to angiopep-2, and was designed to cross the BBB and blood-cerebrospinal barriers and to penetrate malignant cells via the LRP1 transport system. In a phase I study, ANG1005 was detected in recurrent glioma tumors that had been resected 3 to $6 \mathrm{~h}$ after a single intravenous administration of ANG1005, providing evidence of transport across the BBB and tumor penetration, and an antitumor effect was observed in both CNS and peripheral tissue at does ranging from 420 to $650 \mathrm{mg} / \mathrm{m}^{2}$ in patients with BM [166,167]. In a phase II study, adults with recurrent brain metastases from breast cancer, with or without leptomeningeal carcinomatosis were administered ANG1005 intravenously at a dose if $600 \mathrm{mg} / \mathrm{m}^{2}$, resulting in notable CNS antitumor activity and demonstrated good efficacy systemically [165]. A randomized phase III study of ANG1005 is underway to further evaluate the treatment effect seen in patients with leptomeningeal carcinomatosis.

In this above section, we described several transport systems for BBB crossing and some examples of their use in drug delivery, especially nanoparticle-based delivery. While we focused on the three pathways, namely: (1) transporter-mediated transcytosis; (2) clathrin-dependent transcytosis, and (3) caveolae-dependent transcytosis, in terms of nanoparticle-based delivery, it is thought that caveolae-dependent pathways, such as the LDLR-related pathway, may be a more suitable pathway among these from the viewpoint of intracellular trafficking.

\subsection{Mechanism of BBB Crossing (Immune Cells, $A A V$ Vector)}

It is highly difficult to deliver macromolecules into the brain, as mentioned above. One of the rational strategies for achieving this is the use of endogenous transport systems, such as transporters/receptors on the BBB, examples of which were given above. Another useful strategy includes designing DDS carriers based on the migration mechanism of immune cells that migrate into the brain and the mechanism of viral vectors that are currently the most advanced vector for gene therapy. Thus, in this 
section, we summarize several reported mechanisms, namely: (1) the mechanism of immune cell migration into the brain and (2) endogenous factor required for CNS migration of AAV-vectors.

The recruitment of immune cells from the circulation is one of the most dynamic cellular responses to tissue damage and inflammation. Lymphocyte extravasation is regulated by selective interactions between lymphocytes and endothelial cells [168], which can show specificity in relation to the tissue site and/or organ [169]. However, classical thinking indicates that there seems to be no routine immune surveillance of the CNS due to barriers such as BBB. In fact, the CNS is an immune-privileged site, since it is well known that tissue grafts survive well when implanted into the CNS parenchyma [170]. On the other hand, activated lymphocytes can enter the CNS for immune surveillance [171-174]. Studies of the lymphocyte transfer capacity of the barriers (BBB and blood-cerebrospinal fluid barrier (BCSFB)) revealed that the $\mathrm{BBB}$ was breached and lymphocyte populations migrated across the endothelium to accumulate at sites of an antigen challenge during inflammatory processes in the CNS [171]. Three potential immune cell entry sites into the CNS are proposed, and these sites are localized to superficial leptomeningeal vessels, parenchymal vessels, and the choroid plexus [174]. The activation of endothelial cells and associated cells such as astrocytes, which occurs on the development of a CNS injury, lead to the reduced integrity of tight junctions, facilitating the migration of leukocytes across the BBB into the brain $[175,176]$. While molecular pathways for leukocyte entry into the CNS are different depending on the inflammatory stimulus and the CNS compartment affected, adhesion molecules are involved in the migration of leukocytes $[175,177]$. Inflammation in the CNS leads to an increased expression of adhesion molecules on endothelial cells of the BBB, such as the intercellular adhesion molecule-1 (ICAM-1), vascular cell adhesion molecule-1 (VCAM-1), and the platelet endothelial cell adhesion molecule (PECAM1) [178]. These adhesion molecules play important roles in multi-step immune cell trafficking across the $\mathrm{BBB}$, such as capture, rolling, adhesion and diapedesis. It has been reported that a lack of endothelial ICAM-1 and ICAM-2 in a mouse model of the BBB abrogates Th1 cell polarization and crawling [179], and it has also been demonstrated that the cell surface levels of endothelial ICAM-1 rather than BBB integrity influence the pathway of T-cell diapedesis across the BBB [180]. Interestingly, inflammatory conditions with high levels of endothelial ICAM-1 promote the rapid initiation of transcellular diapedesis of T-cells across the BBB, while intermediate levels of endothelial ICAM-1 favor paracellular T-cell diapedesis [180]. Furthermore, in the case of neutrophil diapedesis across the inflamed BBB, it has been shown that $\beta 2$ integrin-mediated crawling on endothelial ICAM-1 and ICAM-2 is a prerequisite for transcellular diapedesis [181]. Considering the above, this mode of ICAM-1-mediated transport may be important under certain types of pathological conditions and relevant for drug delivery exploitation. Actually, it has been reported that nanocarriers modified on the surface by anti-ICAM-1 or VCAM-1 showed a higher uptake in an inflamed brain compared to non-targeted nanocarriers [182-185]. Other reports have proposed "the gateway theory" [186-193]. According to these reports, there is a gateway by which pathogens or immune cells enter the CNS, and the mechanism of gateway formation is a massive chemokine-inducing "inflammation amplifier" through the co-activation of the NF-kB and STAT3 pathways [187,191]. In that report [187], the activation of sensory nerves by artificially weak electrical stimulation of the quadriceps or triceps muscles increased the expression of chemokines and formed vascular gates for immune cells to enter the CNS in the dorsal vessels of the third lumber spinal cord or fifth cervical spinal cord to the fifth thoracic spinal cord, respectively. The location of gateways also depends on regional neural activation [190]. Those results reveal that a gate for CNS entry of immune cells can be controlled by the artificial regional neural activation, and controlling local neural stimulation represents a potential therapeutic strategy for treating inflammatory conditions in the CNS. While there are still many unknowns concerning this and further research is needed, it is possible that the strategic of the engineering biological state by the gateway control could be applied to deliver drugs into the CNS.

The AAV-vector is currently known as the most advanced gene delivery vector for CNS-targeted gene therapy. In a later part of this report, we summarize the CNS-targeted AAV-vector in detail. In this 
section, we introduce the reported mechanism for the crossing of the AAV-vector thorough the BBB. Recently, host cell factors involved in the gene transfer of AAV-vectors have been identified by a variety of comprehensive screenings and analyses [194]. AAV-PHP.B is the most efficient CNS-targeted gene delivery vector in rodents [195]. However, the AAV-PHP.B cannot show CNS tropism in some mouse strains and animal species $[196,197]$. Several research groups used this phenomena and identified a specific haplotype of the lymphocyte antigen 6 complex, locus A (Ly6a) (stem cell antigen-1 [Sca-1]) as the factor required for the BBB crossing of AAV-PHP.B [198-200]. Ly6a molecules are expressed on the surface of the BBB and they have several single nucleotide polymorphisms (SNPs). The results of AAV-PHP.B transduction with/without Ly6a showed that Ly6a facilitates binding and transduction both in vitro and in vivo [198]. Although Ly6a has been identified as an essential factor for the CNS tropism of AAV-PHP.B, primates contain no direct Ly6a homolog. The question therefore arises as to how we utilize this finding to apply gene delivery vectors for humans. It is thought that other cellular factors that share key properties with Ly6a may be prime molecular targets for gene delivery vectors in mice, non-human primates (NHPs), and humans.

\subsection{BBB Breakdown under Pathological Conditions}

The BBB is a highly tight barrier that limits the influx of substances into the brain. However, it has been reported that $\mathrm{BBB}$ disruption occurs under various pathological conditions of diseases such as strokes, traumatic brain injuries, MS, PD, AD, and other brain trauma [58,59]. In sporadic AD, the BBB is structurally and functionally disrupted. For example, the down-regulation of GLUT1 and LDLR, decreased the expression and functionality of ATP-binding cassettes (ABC) transporters [42,201]. Other features of BBB breakdown are summarized in Table 3. Disease-initiated BBB breakdown might present an opportunity for delivering therapeutic agents. Actually, in the pathological condition of ischemia, it is possible for small-sized liposomes to enter into the brain tissue [202]. However, vascular changes in BBB disruption include endothelial degeneration, reduced expression of TJs at the BBB, increased endothelial bulk flow transcytosis, disrupted BBB transporter expression, inflammation, and immune response, can all hinder the delivery of therapeutic agents to the brain. Furthermore, decreased function of carrier-mediated transport (CMT) and receptor-mediated transport (RMT) systems in neurodegenerative diseases complicates their use for therapeutic drug delivery [59]. Given this, we should consider the differences between normal conditions and pathological conditions in both the structures and functions of the BBB for designing an efficient DDS.

Table 3. Blood-brain barrier (BBB) breakdown and dysfunction in pathological conditions.

\begin{tabular}{|c|c|c|}
\hline CNS Disease & The Type of BBB Breakdown and Dysfunction & Reference \\
\hline \multirow{4}{*}{$\mathrm{AD}$} & Down-regulation of glucose transporter 1 (GLUT1) & [201] \\
\hline & Down-regulation of low density lipoprotein receptor (LDLR) & [203] \\
\hline & Decreased expression and functionality of P-gp & [204] \\
\hline & Low expression of tight junction (TJ) proteins & [205] \\
\hline Multiple sclerosis (MS) & $\begin{array}{c}\text { Abundance of chemokines and cytokines, leading to damage } \\
\text { on TJ proteins }\end{array}$ & [206] \\
\hline \multirow{2}{*}{ PD } & Decrease in TJ protein expression, leaky BBB & [207] \\
\hline & Abnormal distribution of GLUT1 & [208] \\
\hline \multirow{3}{*}{ Stroke } & \multirow{3}{*}{$\begin{array}{l}\text { Up-regulation of GLUT1 } \\
\text { Increased BBB permeability }\end{array}$} & [209] \\
\hline & & [210] \\
\hline & & [211] \\
\hline \multirow[b]{2}{*}{ Glioblastoma } & Induction of blood-brain tumor barrier & [212] \\
\hline & $\begin{array}{l}\text { Overexpression of certain receptor-mediated transcytosis } \\
\text { (RMT) }\end{array}$ & [213] \\
\hline
\end{tabular}




\section{AAV Vector; Currently the Most Advanced Gene Delivery Vector}

$\mathrm{AAV}$-vectors are currently known as the most advanced gene delivery vector for crossing the $\mathrm{BBB}$, and they are becoming a platform for the treatment of various neurological diseases [12]. $\mathrm{AAV}$-vectors are used to transduce therapeutic genes to the CNS site for treatment of neurodegenerative disorders [12,65], and many serotypes have been developed by capsid modification strategies, such as directed evolution (Random mutation insertion, DNA shuffling, Peptide display) [214] and rational design [215], as shown in Table 4. Actually, the AAV9 serotype is used as a vector for gene therapy for the treatment of SMA, Zolgensma. In this section, we present some examples of AAV-vectors, especially brain-targeted systems, and summarize the currently-approved gene therapy, Zolgensma for the treatment of SMA. Finally, we briefly outline the challenges to using the AAV-vector at the moment.

Table 4. CNS-targeted Adeno-associated virus (AAV) vectors developed so far.

\begin{tabular}{|c|c|c|c|}
\hline Serotype & $\begin{array}{l}\text { Relative Efficiency } \\
\text { (vs. AAV9) }\end{array}$ & $\begin{array}{c}\text { Notable Features Capsid Mutation } \\
\text { Pattern }\end{array}$ & Reference \\
\hline \multirow{3}{*}{ AAV9 } & \multirow{3}{*}{1} & Neonatal mice $\rightarrow$ neurons & \multirow{3}{*}{ [216] } \\
\hline & & Adult mice $\rightarrow$ astrocytes & \\
\hline & & Used as the vector of Zolgensma & \\
\hline AAV.GTX & & $\begin{array}{l}\text { AAV9 capsid VP1; Y446F and } \\
\text { Y731F } \rightarrow \text { inhibit ubiquitination }\end{array}$ & [217] \\
\hline AAV-PHP.B & \multirow{2}{*}{$<40$} & $\begin{array}{c}\text { AAV9 capsid; } \\
\text { Q588-TLAVPFK-A589 } \rightarrow \text { AAV-PHP.B }\end{array}$ & \multirow{2}{*}{ [195] } \\
\hline AAV-PHP.eB & & $\begin{array}{l}\text { AAV-PHP.B capsid; A587D, } \\
\text { Q588G } \rightarrow \text { AAV-PHP.eB }\end{array}$ & \\
\hline AAV.B1 & $\sim 10$ & $\begin{array}{c}\text { DNA shuffling, Less reactive to } \\
\text { neutralizing antibodies than AAV9 }\end{array}$ & [218] \\
\hline \multirow{2}{*}{ AAV.AS } & \multirow{2}{*}{$\sim 15$} & $\begin{array}{c}\text { AAV9 } 4 \text { amino acids; S414N, G453D, K557E, } \\
\text { T582I } \rightarrow \text { AAV9.47 }\end{array}$ & \multirow[t]{2}{*}{ [219] } \\
\hline & & AAV9.47 VP2; +19 alanine & \\
\hline
\end{tabular}

\subsection{Brain-Targeted AAV Vectors Developed So Far}

AAV-vectors, especially AAV9 serotypes, are used for CNS-targeted gene delivery vectors that are administered non-invasively [216,220-222]. By capsid modification strategies, many serotypes of AAV-vectors have been developed in order to create far more efficient CNS-targeted vectors. AAV9 is the first identified serotype that has the ability to bypass the BBB [216,222]. However, the AAV9 serotype has several limitations in terms of more gene expression in astrocytes compared to neurons in adult animal brains, and the DNA package size. To overcome these limitations, tyrosine-mutant AAV9/3 (AAV.GTX) vectors have been developed [217]. A mutation can enhance gene expression efficiency through the inhibition of intracellular ubiquitination, in addition, the usage of neuron-specific promoters achieved selective transduction of neurons. Several cell type specific/selective AAV-vectors have been reported (brain microvascular endothelial cells [223], astrocytes [224]). In addition, an AAV that targets a specific subpopulation of astrocytes was developed using a specific promoter expressed in the target astrocyte subpopulation [225]. Multiplexed-Cre-recombination-based AAV targeted evolution (M-CREATE) was recently developed as an efficient methodology for identifying variants of interest in a given selection landscape [226]. The M-CREATE could identify capsid variants that can target distinct brain cell types. AAV-PHP.B has been identified by a capsid selection method, referred to as Cre-recombination-based AAV targeted evolution (CREATE), and the AAV-PHP.B shows at least a 40-fold greater transduction efficiency in the CNS compared to conventional standard, AAV9 [195]. As mentioned above, AAV-PHP.B failed to show CNS tropism in some mouse strains and animal species $[196,197]$, and a specific haplotype of the lymphocyte antigen 6 complex, locus A 
(Ly6a) (stem cell antigen-1 [Sca-1]) has been identified as the factor required for AAV-PHP.B to cross the BBB [198-200]. AAV.B1 has been isolated as a novel CNS tropic AAV capsid after a single round of in vivo selection from a DNA shuffled AAV viral library [218]. The AAV.B1 showed a higher efficiency than AAV9 for gene delivery to the mouse brain, together with reduced sensitivity to neutralization by antibodies. AAV.AS, generated by the insertion of a poly-alanine peptide, showed 6- and 15-fold more efficient gene transduction than AAV9 after systemic administration in the spinal cord and cerebrum, respectively [219]. The AAV.AS transduced particularly high in the striatum ( $36 \%$ of striatal neurons). We summarized the AAV serotypes described above in Table 4.

\subsection{Zolgensma; AAV9-Based Gene Therapy to Treat SMA}

In May 2019, the FDA approved a gene therapy for SMA, Zolgensma [25]. It was developed by AveXis, a Novartis company, for the treatment of paediatric patients aged $<2$ years with SMA and bi-allelic mutations in the primary gene encoding the survival motor neuron protein, namely the SMN1 gene. SMA is a rare, progressive genetic disease, yet it is the number one genetic cause of infant death $[227,228]$. The genetic root of SMA is the SMN1 gene that is missing or not functioning properly. If this gene is missing or not functioning properly, the body cannot produce enough SMN protein, which is required for motor neuron survival. There is a backup gene for the SMN1 gene, called the SMN2 gene. However, the SMN2 gene produces only $10 \%$ of the working protein compared to the protein produced by the SMN1 gene. Some people can have more copies of the SMN2 gene and others can have fewer, so there is a wide range of severity in individuals who are affected by SMA, which means that the higher the severity, the fewer backup genes. Zolgensma delivers a functional SMN gene to neurons in order to improve the survival of motor neurons [24]. For SMA treatment, there is an antisense nucleic acid-based drug, called Nusinersen [5] which enhances the production of functional SMN proteins by a exon-inclusion mechanism. Both Zolgensma and Nusinersen demonstrated meaningful improvements in efficacy in clinical trials. There is a report that compares Zolgensma with Nusinersen with regard to the efficacy such as overall survival, event-free survival, improvement in motor function, and motor milestone achievements [229]. The results of Zolgensma (AVXS-101-CL-101; NCT02122952) and Nusinersen (ENDEAR; NCT02193074) clinical trials were indirectly compared in the report. The comparison suggested that Zolgensma may have an advantage relative to Nusinersen in the above items.

\subsection{Controversy Concerning the Use of $A A V$ Vectors}

AAV-vectors are of particular interest as brain-targeted gene delivery vectors, and they are also widely used clinically. However, that does not mean there are no challenges. In fact, there is controversy about Zolgensma. Although significant efficacy was reported, there was a death in the Phase 3 clinical study and detailed findings at necropsy remain unclear. The dose set by Zolgensma appears to be quite high $\left(1.1 \times 10^{14}\right.$ vector genome $(\mathrm{vg}) / \mathrm{kg}$ body weight $)$, and this dose could cause organ damage, an immune response to the viral vector because it is reported that severe toxicities, such as liver damage, and the degeneration of sensory neurons, were observed in NHPs and piglets at $2 \times 10^{14} \mathrm{vg} / \mathrm{kg}$ body weight [230]. Actually, the document says "Zolgensma could result in elevated liver enzymes and cause acute serious liver injury. An oral corticosteroid should be started the day before infusion with Zolgensma". Furthermore, data manipulation was noticed in pre-clinical studies after FDA approval, although FDA has confirmed that it will continue to permit it to sell as it has no impact on safety and the efficacy of the drug [231]. There are also some remaining problems and challenges in terms of the use of the AAV-vectors such as problems associated with tissue-tropism preservation by animal species, neutralization antibodies against $\mathrm{AAV}$, biodistribution after systemic administration, and high dose/large-scale production (cost problem). In this section, we discuss the above two problems, first, problems associated with tissue-tropism preservation by animal species and, second, neutralization antibodies against AAV. 
Although some AAV-vector serotypes can produce efficient CNS tropism, there are differences in the pattern of CNS biodistribution in NHPs compared with mice. AAV-PHP.B has recently been shown to transduce the brains of mice with a higher efficiency compared with its parent serotype, AAV9, as mentioned above. Although AAV-PHP.B showed widespread and largely equal CNS transduction in mice following different injection strategies including two intravascular (intra-jugular vein and intra-carotid artery) and two intra-CSF routes (intra-cisterna magna and intra-lateral ventricle), a differential pattern of transduction in macaques was observed with broad cortical and spinal cord transduction being observed after intrathecal administration and only very low transduction following intravascular injection [197]. How do we apply the AAV-vectors to human use if there are differences in tissue-tropism depending on animal species? One solution is to devise a route of administration of the AAV-vectors such as is described in reference [197], but it is not desirable if the suitable route of administration is invasive method.

Since AAV infections occur naturally in humans, some patients can have pre-existing immunity. AAV was actively studied in the 1960s and 1970s, and AAV1-4 serotypes were identified at that time, and the positive rate of each neutralizing antibody was measured [232]. The results showed that the majority of the subjects are positive. Other reports also examined the prevalence of neutralizing antibodies against AAV serotypes [233-235]. The findings suggested that the destruction of transduced hepatocytes by cell-mediated immunity targeting antigens of the AAV capsid caused both the decline in gene expression and the transient transaminitis [236]. Gene expression was observed in monkeys with AAV8-neutralizing antibody-negative individuals, but not in positive individuals [237], indicating that neutralizing antibodies greatly affect the therapeutic effect. The neutralizing antibody positive rate tended to increase with increasing age [233]. Initially, the AAV-vector was administered by the direct injection into the target tissue, but was subsequently replaced by transvascular administration [238], which makes it more susceptible to neutralizing antibodies. Considering the above, the issue of whether a patient has neutralizing antibodies against AAV before the treatment usage should be demonstrated, and it appears that it would be more difficult to use AAV for older patients compared to younger patients.

\section{Non-Viral Brain Targeting by Non-Invasive Methods}

Viral vectors have a significantly higher transfection efficiency in comparison to non-viral vectors [61-63]. However, as mentioned above, there are several problems and challenges to the use of viral vectors with regard to their efficacy and safety profiles. In terms of those points, non-viral vectors offer some advantages, a safer and more flexible route to gene delivery [68-70], even in brain targeting [239-241]. As shown in Figure 5, there are several non-viral strategies for brain targeting using non-invasive methods. The purpose of this section is to present non-viral methods and focus on systemically injected non-viral systems for brain targeting as follows; (1) Active targeting using ligands/peptides-modification; (2) Protein corona (endogenous ligands); (3) Transient BBB disruption.

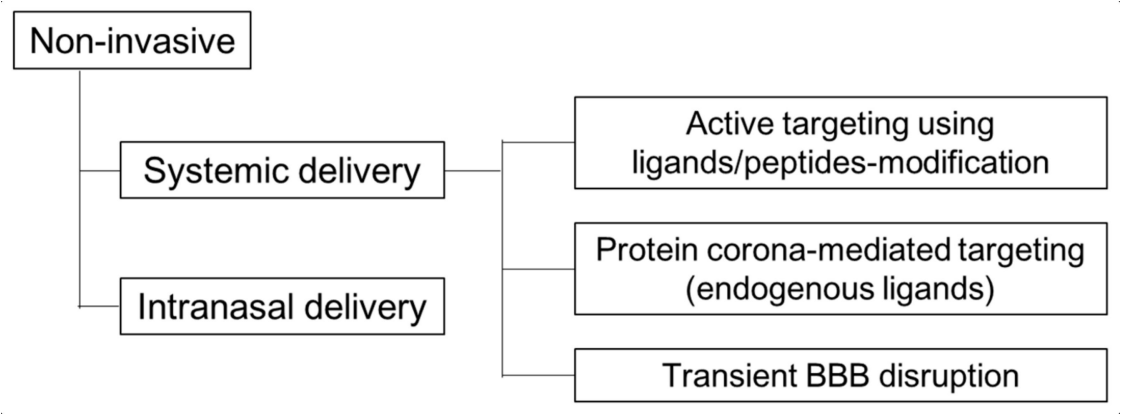

Figure 5. Non-viral strategies for brain targeting by non-invasive methods. 


\subsection{Active Targeting Using Ligands/Peptides-Modification}

Most studies of drug delivery to the brain use active targeting approaches in order to produce a high brain-selectivity and reduce possible side effects. An active targeting strategy is a simple concept in which specific receptors/transporters present on the brain cells are used for targeting. This section provides an overview of reports on brain targeting with targeted-ligands, especially in macromolecule delivery such as proteins and nucleic acids.

One elegant and non-invasive strategy is to utilize peptides derived from neurotropic viruses or organisms as the targeting ligand. Peptide derivatives of the rabies virus glycoprotein (RVG) have been exploited as delivery ligands to target the brain [242,243]. The reason for using RVG for brain targeting can be explained by the features associated with rabies virus infections. The virus is bullet-shaped, with a length of $200 \mathrm{~nm}$ and a diameter of $80 \mathrm{~nm}$ [244]. The virion carries the RVG on the surface, which is responsible for cellular entry and virus fusion [245]. Based on the above facts, RVG would be a candidate for the use in brain-targeting. However, the rabies virus usually utilizes retrograde transport within the neuronal network to spread from the site of infection to the CNS, and the issue of whether the virus can penetrate the BBB is not known with certainty [246,247]. It is thought that peptide derivatives of RVG use different pathways to gain access to the brain as opposed to rabies virus. It has been documented that RVG mediates the delivery of small interfering RNA (siRNA) to the brain [48]. In that report, a chimeric peptide was synthesized by adding arginine residues at the carboxy terminus of RVG to enable siRNA binding. This RVG-9R delivered siRNA to neuronal cells after intravenous injection into mice, resulting in specific gene silencing in the brain. The proposed targeting mechanism suggests that the peptides and their conjugates specifically bind to nicotinic acetylcholine receptors on the $\mathrm{BBB}$, and then penetrate the BBB by receptor-mediated transcytosis. Applications of RVG have also been explored for delivering therapeutic proteins and plasmid DNA (pDNA) to treat CNS diseases. Peptides derived from the RVG (RDP) delivered protein/plasmid-brain-derived neurotrophic factor (BDNF) into the brain and showed a therapeutic effect on stroke/PD model mice [248,249]. Furthermore, the RVG was used for brain targeted genome editing in adult mice by the injection of RVG-Cre into Cre reporter mouse lines via the tail vein [250].

As mentioned above, GLUT1 is often used as a target molecule for brain drug delivery since it is abundantly expressed on the BBB. However, in the case of nanoparticles for delivering macromolecules such as proteins and nucleic acids, it appears to need to take advantage of transporter recycling instead of the usual transport pathway of GLUT1. There are reports on brain delivery via GLUT1 by utilizing recycling [56,57]. In these reports, not only the precisely controlled glucose density on the surface of the nanocarrier but also glycemic control as an external trigger showed a dramatically enhanced brain accumulation of the carrier ( $>6 \%$ injected dose/g of brain), resulting in significant knockdown of a target RNA in various brain regions by an antisense oligonucleotide that was encapsulated in the carrier.

\subsection{Protein Corona (Endogenous Ligands)}

Despite an abundance of preclinical studies on nanomedicines, its clinical translation is still limited. One of the possible factors may be the formation of a "protein corona" on nanoparticles. It is widely accepted that once nanoparticles are systemically administered, they encounter serum components, such as proteins, resulting in the formation of a protein corona on the surface $[137,138,141,146,251-254]$. Protein corona formation is a double-edged sword, which means controlling them can be applied to more effective targeting [51,54,55,148-154] although protein corona formation on the nanoparticle surface may adversely affect the targeting [147]. With regard to brain targeting, ApoE is a well-known endogenous ligand, and brain delivery using nanoparticles with suitable affinity for ApoE has been conducted. As mentioned above, polysorbate- 80 coated nanoparticles can bind to ApoE and enter the brain via a LDLR-mediated pathway [51,155-157]. There appears to be two modification modalities for controlling the protein corona, pre-coating before injection and controlled corona formation in the circulation. As an example of the former, it was reported that pre-ApoE4 decorated nanoparticles showed an 
improved brain accumulation compared to un-decorated nanoparticles [51]. However, random protein adsorption can cause access to the receptor-binding pocket to be inhibited $[255,256]$. It is thought that this can be avoided if the interaction mode of protein adsorption on nanocarrier-surface can be controlled. The latter example is that precisely manipulating the binding pattern of brain targeted apolipoproteins on the nanoparticle surface resulted in superior brain accumulation and showed a therapeutic efficacy in a glioma tumor model [54]. In the report, the liposomal surface was modified with a short nontoxic peptide derived from $\beta$-amyloid $\left(A \beta_{1-42}\right)$, which specifically interacts with the lipid-binding domain of apolipoproteins, for manipulating the modes of apolipoprotein adsorption. The liposomal system developed in this study led to the association of brain-targeting proteins in the circulation, and the receptor binding domains of these proteins were appropriately exposed on liposomal surface in the blood stream. The modification of brain targeting plasma proteins in the circulation has the potential to overcome the following drawbacks to the use of protein-modifications for clinical translation [257,258]: (1) protein modification makes production, storage, and transportation costly; (2) elevating immunogenicity is a risk; (3) the endogenous brain targeting protein competes with the receptor binding of the carriers.

\subsection{Transient BBB Disruption}

Finally, we briefly introduce a transient BBB opening strategies by using external stimuli (micro-bubbles (MBs) and focused ultrasound (FUS)) and others (chemical methods). Transient drug or gene delivery to the brain is possible by FUS irradiation of the brain following the intravenous administration of MBs [259-263]. FUS irradiation of a targeted region of the brain and the presence of MBs in the blood cause the transient disruption of the BBB, leading to promoting the permeation of nanoparticle through the BBB. Several reports demonstrated that FUS and MBs can be utilized to deliver therapeutic genes for curing neurodegenerative disease, especially in a PD mouse model [264-269]. There is strong evidence to show that neurotrophic factor can promote the regeneration of dopaminergic neurons to releive the PD syndrome [270-272]. The glial cell line-derived neurotrophic factor (GDNF) is one of the potent agents for PD treatment because of its neuroprotective and neurotrophic effects [272,273]. FUS and MBs increased brain gene transfection and dopamine levels were restored by FUS-triggered MBs GDNF gene delivered treatment, which produced an abnormal rotation reduction in PD mice [267] and rats [265]. There are several methods available for transiently disrupting the BBB in addition to FUS and MBs. One of the strategies involves the use of chemical compounds, such as Borneol $[274,275]$, mannitol [276] and an adenosine receptor agonist [277-279]. Borneol, which is widely used as messenger drug in traditional Chinese medicine, can enhance drug permeation through various membranes including the BBB [274]. A recent report suggests that elevated levels of the expression of the intracellular cell adhesion molecule-1 (ICAM-1) contributes to Borneol gaining access to the BBB, although the detailed mechanism is unknown [275]. Mannitol can also cause chemical destruction resulting in the opening of the BBB by changing the osmotic pressure [276]. Adenosine receptors have been considered to be therapeutic targets in many diseases including CNS disorders [280], and it has been reported that the activation of adenosine receptors could elevate the permeability of the BBB in vivo [279]. In that report, lexiscan, an agonist of A2A adenosine receptors, -conjugated dendrimers (nanoagonists) improved the accumulation of a model drug in the brains of mice that had been pretreated with nanoagonists compared to dendrimers without lexiscan. It will be important to verify the risk of foreign invasion into the brain through the opening of intracellular gaps. Furthermore, it should be noted here that it is necessary to adjust this so as not to cause chronic BBB disruption since chronic disruption is injurious to the brain and induces neurodegeneration [281]. Considering the above, it may be better to use the transient BBB disruption method for the treatment of regional diseases such as brain cancer.

The above section highlights three mainly used non-viral strategies focused on systemically injected non-invasive methods. There are, however, other non-invasive methods such as intranasal delivery that are beyond the scope of this report, but have also been efficient in allowing the delivery 
of therapeutic agents [282]. Briefly, intranasal delivery is a non-invasive method, known as the nose-to-brain route, for delivering various therapeutic molecules including small molecules [283], proteins [284,285], and oligonucleotides as well [286] and gene delivery vectors [287,288]. There are two proposed pathways for intranasal delivery bypassing the BBB: the olfactory pathway and the trigeminal pathway. In the former, agents are distributed in the olfactory bulb through axonal transport by their nerves or passage through the nasal epithelium. In the latter, agents are distributed in the hypothalamus and brainstem. There are still obstacles to overcome, such as the mucus layer and the epithelium, where efflux transporters and several metabolizing enzymes are located. Other limitations to the intranasal delivery include the restricted volume of administration. For more information about other options, the readers are referred to other reviews and reports [282,289-293].

\section{Summary and Future Directions}

The development of new drugs for the treatment of neurological disorders, such as AD, PD, and strokes, which are the most burdensome diseases, globally and socially, is highly desired. Although gene therapy has great promise for the treatment of those neurological disorders, the delivery of therapeutic agents to the brain is the biggest hurdle. Thus, the development of brain-targeted DDS is as important as or even important than the drug itself. When designing a rational brain-targeted system, we should consider the differences in BBB structures and functions between normal conditions and pathological conditions. As represented by Zolgensma, AAV-vectors are the most advanced gene delivery vector for gene therapy, however, there are several remaining problems and challenges such as tissue-tropism preservation among animal species, and neutralization antibodies against AAV. On the other hand, non-viral gene delivery systems are safer, more flexible, and a cost-effective route compared to viral vectors. Actually, non-viral vectors have been reported and they have potential for the treatment of CNS diseases such as strokes, cancer, and neurological disorders. Although studies for developing brain-targeted non-viral gene delivery systems are currently in progress, the efficiency of expression continues to be inferior to that of viral vectors. We do not know the precise level of expression of therapeutic genes needed to produce therapeutic effects on CNS diseases. The efficiency of non-viral vectors may need to be improved, but there is no need to compete with viral vectors as long as the expression efficiency is sufficient to exert a therapeutic effect. It is possible that we will need quantitative data regarding the amount of therapeutic gene expression that is needed to cure the diseases for the purpose. As a common point of view between viral and non-viral vectors, it should be considered that brain-targeted vectors can accumulate in tissues other than the brain. Finding more specific targets and/or preventing other tissue accumulation are thought to be strategies for developing more brain-selective carriers. In order to achieve this, we will need to understand the biological mechanisms in healthy/pathological conditions, the characteristics of delivery vectors and the modality of interaction between the vectors and the living body. Mechanistic studies and some screening may be required to accomplish this. Although the present state of CNS-targeted drug development is still in the initial stage, recent promising innovations and future persistent research may provide us with novel and efficient drugs for treating CNS disorders.

Funding: This research received no external funding.

Acknowledgments: This work was supported by the Nagai Memorial Research Scholarship from the Pharmaceutical Society of Japan. We wish to thank Milton Feather for his helpful advice in editing this manuscript.

Conflicts of Interest: The authors declare no conflict of interest.

\section{References}

1. Feigin, V.L.; Vos, T.; Nichols, E.; Owolabi, M.O.; Carroll, W.M.; Dichgans, M.; Deuschl, G.; Parmar, P.; Brainin, M.; Murray, C. The global burden of neurological disorders: Translating evidence into policy. Lancet Neurol. 2020, 19, 255-265. [CrossRef] 
2. Japan Health Sciences Foundation. 2019年度国内基盤技術調査報告書「60疾患に関する医療ニーズ調査」。 Available online: http://www.jhsf.or.jp/paper/report.html\#top_2019 (accessed on 16 July 2020).

3. Pardridge, W.M. The blood-brain barrier: Bottleneck in brain drug development. NeuroRx 2005, 2, 3-14. [CrossRef] [PubMed]

4. Saunus, J.M.; McCart Reed, A.E.; Lim, Z.L.; Lakhani, S.R. Breast Cancer Brain Metastases: Clonal Evolution in Clinical Context. Int. J. Mol. Sci. 2017, 18, 152. [CrossRef] [PubMed]

5. Chiriboga, C.A. Nusinersen for the treatment of spinal muscular atrophy. Expert Rev. Neurother. 2017, 17, 955-962. [CrossRef] [PubMed]

6. スピンラザ骾注12 mg. Available online: https://www.info.pmda.go.jp/go/pack/1190403A1022_1_03/ (accessed on 22 July 2020).

7. Khorkova, O.; Wahlestedt, C. Oligonucleotide therapies for disorders of the nervous system. Nat. Biotechnol. 2017, 35, 249-263. [CrossRef] [PubMed]

8. Ginn, S.L.; Amaya, A.K.; Alexander, I.E.; Edelstein, M.; Abedi, M.R. Gene Therapy Clinical Trials Worldwide to 2017: An Update. J. Gene Med. 2018, 20. [CrossRef] [PubMed]

9. Piguet, F.; Alves, S.; Cartier, N. Clinical Gene Therapy for Neurodegenerative Diseases: Past, Present, and Future. Hum. Gene Ther. 2017, 28, 988-1003. [CrossRef] [PubMed]

10. Dunbar, C.E.; High, K.A.; Joung, J.K.; Kohn, D.B.; Ozawa, K.; Sadelain, M. Gene therapy comes of age. Science 2018, 359, eaan4672. [CrossRef]

11. Choong, C.J.; Baba, K.; Mochizuki, H. Gene therapy for neurological disorders. Expert Opin. Biol. Ther. 2016, 16, 143-159. [CrossRef]

12. Deverman, B.E.; Ravina, B.M.; Bankiewicz, K.S.; Paul, S.M.; Sah, D.W.Y. Gene therapy for neurological disorders: Progress and prospects. Nat. Rev. Drug Discov. 2018, 17, 641-659. [CrossRef]

13. Gessler, D.J.; Gao, G. Gene Therapy for the Treatment of Neurological Disorders: Metabolic Disorders. Methods Mol. Biol. 2016, 1382, 429-465. [CrossRef] [PubMed]

14. Ingusci, S.; Verlengia, G.; Soukupova, M.; Zucchini, S.; Simonato, M. Gene Therapy Tools for Brain Diseases. Front. Pharmacol. 2019, 10, 724. [CrossRef] [PubMed]

15. Sudhakar, V.; Richardson, R.M. Gene Therapy for Neurodegenerative Diseases. Neurotherapeutics 2019, 16, 166-175. [CrossRef] [PubMed]

16. Eberling, J.L.; Jagust, W.J.; Christine, C.W.; Starr, P.; Larson, P.; Bankiewicz, K.S.; Aminoff, M.J. Results from a phase I safety trial of hAADC gene therapy for Parkinson disease. Neurology 2008, 70, 1980-1983. [CrossRef] [PubMed]

17. LeWitt, P.A.; Rezai, A.R.; Leehey, M.A.; Ojemann, S.G.; Flaherty, A.W.; Eskandar, E.N.; Kostyk, S.K.; Thomas, K.; Sarkar, A.; Siddiqui, M.S.; et al. AAV2-GAD gene therapy for advanced Parkinson's disease: A double-blind, sham-surgery controlled, randomised trial. Lancet Neurol. 2011, 10, 309-319. [CrossRef]

18. Hardy, J.; Allsop, D. Amyloid deposition as the central event in the aetiology of Alzheimer's disease. Trends Pharmacol. Sci. 1991, 12, 383-388. [CrossRef]

19. Holtzman, D.M.; Herz, J.; Bu, G. Apolipoprotein E and apolipoprotein E receptors: Normal biology and roles in Alzheimer disease. Cold Spring Harb Perspect Med. 2012, 2, a006312. [CrossRef]

20. Shi, Y.; Yamada, K.; Liddelow, S.A.; Smith, S.T.; Zhao, L.; Luo, W.; Tsai, R.M.; Spina, S.; Grinberg, L.T.; Rojas, J.C.; et al. ApoE4 markedly exacerbates tau-mediated neurodegeneration in a mouse model of tauopathy. Nature 2017, 549, 523-527. [CrossRef]

21. Huang, Y.A.; Zhou, B.; Wernig, M.; Südhof, T.C. ApoE2, ApoE3, and ApoE4 Differentially Stimulate APP Transcription and A $\beta$ Secretion. Cell 2017, 168, 427-441.e21. [CrossRef]

22. Sun, J.; Carlson-Stevermer, J.; Das, U.; Shen, M.; Delenclos, M.; Snead, A.M.; Koo, S.Y.; Wang, L.; Qiao, D.; Loi, J.; et al. CRISPR/Cas9 editing of APP C-terminus attenuates $\beta$-cleavage and promotes $\alpha$-cleavage. Nat. Commun. 2019, 10, 53. [CrossRef]

23. Tanaka, H.; Kondo, K.; Chen, X.; Homma, H.; Tagawa, K.; Kerever, A.; Aoki, S.; Saito, T.; Saido, T.; Muramatsu, S.I.; et al. The intellectual disability gene PQBP1 rescues Alzheimer's disease pathology. Mol. Psychiatry 2018, 23, 2090-2110. [CrossRef]

24. Mendell, J.R.; Al-Zaidy, S.; Shell, R.; Arnold, W.D.; Rodino-Klapac, L.R.; Prior, T.W.; Lowes, L.; Alfano, L.; Berry, K.; Church, K.; et al. Single-Dose Gene-Replacement Therapy for Spinal Muscular Atrophy. N. Engl. J. Med. 2017, 377, 1713-1722. [CrossRef] [PubMed] 
25. Hoy, S.M. Onasemnogene Abeparvovec: First Global Approval. Drugs 2019, 79, 1255-1262. [CrossRef] [PubMed]

26. Yu, W.; Fang, H. Clinical trials with oncolytic adenovirus in China. Curr. Cancer Drug Targets 2007, 7, 141-148. [CrossRef] [PubMed]

27. Bryant, L.M.; Christopher, D.M.; Giles, A.R.; Hinderer, C.; Rodriguez, J.L.; Smith, J.B.; Traxler, E.A.; Tycko, J.; Wojno, A.P.; Wilson, J.M. Lessons learned from the clinical development and market authorization of Glybera. Hum. Gene Ther. Clin. Dev. 2013, 24, 55-64. [CrossRef]

28. Pol, J.; Kroemer, G.; Galluzzi, L. First oncolytic virus approved for melanoma immunotherapy. Oncoimmunology 2016, 5, e1115641. [CrossRef] [PubMed]

29. Schimmer, J.; Breazzano, S. Investor Outlook: Rising from the Ashes; GSK's European Approval of Strimvelis for ADA-SCID. Hum. Gene Ther. Clin. Dev. 2016, 27, 57-61. [CrossRef] [PubMed]

30. Sheridan, C. First approval in sight for Novartis' CAR-T therapy after panel vote. Nat. Biotechnol. 2017, 35, 691-693. [CrossRef]

31. FDA Approves Second CAR T-cell Therapy. Cancer Discov. 2018, 8, 5-6. [CrossRef]

32. Schuessler-Lenz, M.; Enzmann, H.; Vamvakas, S. Regulators' Advice Can Make a Difference: European Medicines Agency Approval of Zynteglo for Beta Thalassemia. Clin. Pharmacol. Ther. 2020, 107, 492-494. [CrossRef]

33. Morabito, G.; Giannelli, S.G.; Ordazzo, G.; Bido, S.; Castoldi, V.; Indrigo, M.; Cabassi, T.; Cattaneo, S.; Luoni, M.; Cancellieri, C.; et al. AAV-PHP.B-Mediated Global-Scale Expression in the Mouse Nervous System Enables GBA1 Gene Therapy for Wide Protection from Synucleinopathy. Mol. Ther. 2017, 25, 2727-2742. [CrossRef] [PubMed]

34. Zharikov, A.D.; Cannon, J.R.; Tapias, V.; Bai, Q.; Horowitz, M.P.; Shah, V.; El Ayadi, A.; Hastings, T.G.; Greenamyre, J.T.; Burton, E.A. shRNA targeting $\alpha$-synuclein prevents neurodegeneration in a Parkinson's disease model. J. Clin. Investig. 2015, 125, 2721-2735. [CrossRef]

35. Dodart, J.C.; Marr, R.A.; Koistinaho, M.; Gregersen, B.M.; Malkani, S.; Verma, I.M.; Paul, S.M. Gene delivery of human apolipoprotein E alters brain Abeta burden in a mouse model of Alzheimer's disease. Proc. Natl. Acad. Sci. USA 2005, 102, 1211-1216. [CrossRef] [PubMed]

36. Liu, W.; Zhao, L.; Blackman, B.; Parmar, M.; Wong, M.Y.; Woo, T.; Yu, F.; Chiuchiolo, M.J.; Sondhi, D.; Kaminsky, S.M.; et al. Vectored Intracerebral Immunization with the Anti-Tau Monoclonal Antibody PHF1 Markedly Reduces Tau Pathology in Mutant Tau Transgenic Mice. J. Neurosci. 2016, 36, 12425-12435. [CrossRef]

37. Gaj, T.; Ojala, D.S.; Ekman, F.K.; Byrne, L.C.; Limsirichai, P.; Schaffer, D.V. In Vivo genome editing improves motor function and extends survival in a mouse model of ALS. Sci. Adv. 2017, 3, eaar3952. [CrossRef] [PubMed]

38. Mis, M.S.C.; Brajkovic, S.; Tafuri, F.; Bresolin, N.; Comi, G.P.; Corti, S. Development of Therapeutics for C9ORF72 ALS/FTD-Related Disorders. Mol. Neurobiol. 2017, 54, 4466-4476. [CrossRef]

39. Becker, L.A.; Huang, B.; Bieri, G.; Ma, R.; Knowles, D.A.; Jafar-Nejad, P.; Messing, J.; Kim, H.J.; Soriano, A.; Auburger, G.; et al. Therapeutic reduction of ataxin-2 extends lifespan and reduces pathology in TDP-43 mice. Nature 2017, 544, 367-371. [CrossRef] [PubMed]

40. Pardridge, W.M. Blood-Brain Barrier and Delivery of Protein and Gene Therapeutics to Brain. Front. Aging Neurosci. 2020, 11. [CrossRef] [PubMed]

41. Rabiei, M.; Kashanian, S.; Samavati, S.S.; Jamasb, S.; McInnes, S.J.P. Active Targeting Towards and Inside the Brain based on Nanoparticles: A Review. Curr. Pharm. Biotechnol. 2020, 21, 374-383. [CrossRef]

42. Moura, R.P.; Martins, C.; Pinto, S.; Sousa, F.; Sarmento, B. Blood-brain barrier receptors and transporters: An insight on their function and how to exploit them through nanotechnology. Expert Opin. Drug Deliv. 2019, 16, 271-285. [CrossRef]

43. Wiley, D.T.; Webster, P.; Gale, A.; Davis, M.E. Transcytosis and brain uptake of transferrin-containing nanoparticles by tuning avidity to transferrin receptor. Proc. Natl. Acad. Sci. USA 2013, 110, 8662-8667. [CrossRef] [PubMed]

44. Yan, F.; Wang, Y.; He, S.; Ku, S.; Gu, W.; Ye, L. Transferrin-conjugated, fluorescein-loaded magnetic nanoparticles for targeted delivery across the blood-brain barrier. J. Mater. Sci. Mater. Med. 2013, 24, 2371-2379. [CrossRef] [PubMed] 
45. Clark, A.J.; Davis, M.E. Increased brain uptake of targeted nanoparticles by adding an acid-cleavable linkage between transferrin and the nanoparticle core. Proc. Natl. Acad. Sci. USA 2015, 112, 12486-12491. [CrossRef] [PubMed]

46. Dos Santos Rodrigues, B.; Arora, S.; Kanekiyo, T.; Singh, J. Efficient neuronal targeting and transfection using RVG and transferrin-conjugated liposomes. Brain Res. 2020, 1734, 146738. [CrossRef] [PubMed]

47. Gupta, Y.; Jain, A.; Jain, S.K. Transferrin-conjugated solid lipid nanoparticles for enhanced delivery of quinine dihydrochloride to the brain. J. Pharm. Pharmacol. 2007, 59, 935-940. [CrossRef] [PubMed]

48. Kumar, P.; Wu, H.; McBride, J.L.; Jung, K.E.; Kim, M.H.; Davidson, B.L.; Lee, S.K.; Shankar, P.; Manjunath, N. Transvascular delivery of small interfering RNA to the central nervous system. Nature 2007, 448, $39-43$. [CrossRef] [PubMed]

49. Alvarez-Erviti, L.; Seow, Y.; Yin, H.; Betts, C.; Lakhal, S.; Wood, M.J. Delivery of siRNA to the mouse brain by systemic injection of targeted exosomes. Nat. Biotechnol. 2011, 29, 341-345. [CrossRef]

50. Hwang, D.W.; Son, S.; Jang, J.; Youn, H.; Lee, S.; Lee, D.; Lee, Y.S.; Jeong, J.M.; Kim, W.J.; Lee, D.S. A brain-targeted rabies virus glycoprotein-disulfide linked PEI nanocarrier for delivery of neurogenic microRNA. Biomaterials 2011, 32, 4968-4975. [CrossRef]

51. Dal Magro, R.; Albertini, B.; Beretta, S.; Rigolio, R.; Donzelli, E.; Chiorazzi, A.; Ricci, M.; Blasi, P.; Sancini, G. Artificial apolipoprotein corona enables nanoparticle brain targeting. Nanomedicine 2018, 14, 429-438. [CrossRef]

52. Shubar, H.M.; Dunay, I.R.; Lachenmaier, S.; Dathe, M.; Bushrab, F.N.; Mauludin, R.; Müller, R.H.; Fitzner, R.; Borner, K.; Liesenfeld, O. The role of apolipoprotein $\mathrm{E}$ in uptake of atovaquone into the brain in murine acute and reactivated toxoplasmosis. J. Drug Target 2009, 17, 257-267. [CrossRef]

53. Molino, Y.; David, M.; Varini, K.; Jabès, F.; Gaudin, N.; Fortoul, A.; Bakloul, K.; Masse, M.; Bernard, A.; Drobecq, L.; et al. Use of LDL receptor-targeting peptide vectors for in vitro and in vivo cargo transport across the blood-brain barrier. Faseb J. 2017, 31, 1807-1827. [CrossRef]

54. Zhang, Z.; Guan, J.; Jiang, Z.; Yang, Y.; Liu, J.; Hua, W.; Mao, Y.; Li, C.; Lu, W.; Qian, J.; et al. Brain-targeted drug delivery by manipulating protein corona functions. Nat. Commun. 2019, 10, 3561. [CrossRef] [PubMed]

55. Arcella, A.; Palchetti, S.; Digiacomo, L.; Pozzi, D.; Capriotti, A.L.; Frati, L.; Oliva, M.A.; Tsaouli, G.; Rota, R.; Screpanti, I.; et al. Brain Targeting by Liposome-Biomolecular Corona Boosts Anticancer Efficacy of Temozolomide in Glioblastoma Cells. ACS Chem. Neurosci. 2018. [CrossRef] [PubMed]

56. Anraku, Y.; Kuwahara, H.; Fukusato, Y.; Mizoguchi, A.; Ishii, T.; Nitta, K.; Matsumoto, Y.; Toh, K.; Miyata, K.; Uchida, S.; et al. Glycaemic control boosts glucosylated nanocarrier crossing the BBB into the brain. Nat. Commun. 2017, 8, 1001. [CrossRef] [PubMed]

57. Min, H.S.; Kim, H.J.; Naito, M.; Ogura, S.; Toh, K.; Hayashi, K.; Kim, B.S.; Fukushima, S.; Anraku, Y.; Miyata, K.; et al. Systemic Brain Delivery of Antisense Oligonucleotides across the Blood-Brain Barrier with a Glucose-Coated Polymeric Nanocarrier. Angew. Chem. Int. Ed. Engl. 2020, 59, 8173-8180. [CrossRef] [PubMed]

58. Sweeney, M.D.; Zhao, Z.; Montagne, A.; Nelson, A.R.; Zlokovic, B.V. Blood-Brain Barrier: From Physiology to Disease and Back. Physiol. Rev. 2019, 99, 21-78. [CrossRef] [PubMed]

59. Sweeney, M.D.; Sagare, A.P.; Zlokovic, B.V. Blood-brain barrier breakdown in Alzheimer disease and other neurodegenerative disorders. Nat. Rev. Neurol. 2018, 14, 133-150. [CrossRef] [PubMed]

60. Zlokovic, B.V. The blood-brain barrier in health and chronic neurodegenerative disorders. Neuron 2008, 57, 178-201. [CrossRef]

61. Hama, S.; Akita, H.; Ito, R.; Mizuguchi, H.; Hayakawa, T.; Harashima, H. Quantitative comparison of intracellular trafficking and nuclear transcription between adenoviral and lipoplex systems. Mol. Ther. 2006, 13, 786-794. [CrossRef]

62. Hama, S.; Akita, H.; Iida, S.; Mizuguchi, H.; Harashima, H. Quantitative and mechanism-based investigation of post-nuclear delivery events between adenovirus and lipoplex. Nucleic Acids Res. 2007, 35, 1533-1543. [CrossRef]

63. Varga, C.M.; Tedford, N.C.; Thomas, M.; Klibanov, A.M.; Griffith, L.G.; A Lauffenburger, D. Quantitative comparison of polyethylenimine formulations and adenoviral vectors in terms of intracellular gene delivery processes. Gene Ther. 2005, 12, 1023-1032. [CrossRef] [PubMed]

64. Osten, P.; Grinevich, V.; Cetin, A. Viral vectors: A wide range of choices and high levels of service. Handb. Exp. Pharmacol. 2007, 178, 177-202. [CrossRef] 
65. Hocquemiller, M.; Giersch, L.; Audrain, M.; Parker, S.; Cartier, N. Adeno-Associated Virus-Based Gene Therapy for CNS Diseases. Hum. Gene Ther. 2016, 27, 478-496. [CrossRef] [PubMed]

66. Li, C.; Samulski, R.J. Engineering adeno-associated virus vectors for gene therapy. Nat. Rev. Genet. 2020, 21, 255-272. [CrossRef]

67. Naso, M.F.; Tomkowicz, B.; Perry, W.L., 3rd; Strohl, W.R. Adeno-Associated Virus (AAV) as a Vector for Gene Therapy. BioDrugs 2017, 31, 317-334. [CrossRef]

68. Ramamoorth, M.; Narvekar, A. Non viral vectors in gene therapy-An overview. J. Clin. Diagn Res. 2015, 9, Ge01-06. [CrossRef]

69. Helal, N.A.; Osami, A.; Helmy, A.; McDonald, T.; Shaaban, L.A.; Nounou, M.I. Non-viral gene delivery systems: Hurdles for bench-to-bedside transformation. Pharmazie 2017, 72, 627-693. [CrossRef]

70. Yin, H.; Kanasty, R.L.; Eltoukhy, A.A.; Vegas, A.J.; Dorkin, J.R.; Anderson, D.G. Non-viral vectors for gene-based therapy. Nat. Rev. Genet. 2014, 15, 541-555. [CrossRef]

71. Meng, F.; Wang, J.; Ping, Q.; Yeo, Y. Quantitative Assessment of Nanoparticle Biodistribution by Fluorescence Imaging, Revisited. ACS Nano 2018, 12, 6458-6468. [CrossRef]

72. Varga, C.M.; Hong, K.; Lauffenburger, D.A. Quantitative analysis of synthetic gene delivery vector design properties. Mol. Ther. 2001, 4, 438-446. [CrossRef]

73. Uchida, S.; Kataoka, K. Design concepts of polyplex micelles for in vivo therapeutic delivery of plasmid DNA and messenger RNA. J. Biomed. Mater. Res. A 2019, 107, 978-990. [CrossRef] [PubMed]

74. Buck, J.; Grossen, P.; Cullis, P.R.; Huwyler, J.; Witzigmann, D. Lipid-Based DNA Therapeutics—Hallmarks of Non-Viral Gene Delivery. ACS Nano 2019. [CrossRef] [PubMed]

75. Glebova, K.V.; Marakhonov, A.V.; Baranova, A.V.; Skublov, M.I. [Types of Non-Viral Delivery Systems of Small Interfering RNA]. Mol. Biol. 2012, 46, 387-401. [CrossRef]

76. Chen, J.; Guo, Z.; Tian, H.; Chen, X. Production and Clinical Development of Nanoparticles for Gene Delivery. Mol. Ther. Methods Clin. Dev. 2016, 3. [CrossRef]

77. Hoy, S.M. Patisiran: First Global Approval. Drugs 2018, 78, 1625-1631. [CrossRef]

78. Daneman, R.; Prat, A. The blood-brain barrier. Cold Spring Harb Perspect Biol. 2015, 7, a020412. [CrossRef]

79. Abbott, N.J.; Rönnbäck, L.; Hansson, E. Astrocyte-endothelial interactions at the blood-brain barrier. Nat. Rev. Neurosci. 2006, 7, 41-53. [CrossRef]

80. Stamatovic, S.M.; Keep, R.F.; Andjelkovic, A.V. Brain endothelial cell-cell junctions: How to "open" the blood brain barrier. Curr. Neuropharmacol. 2008, 6, 179-192. [CrossRef]

81. Serlin, Y.; Shelef, I.; Knyazer, B.; Friedman, A. Anatomy and physiology of the blood-brain barrier. Semin. Cell Dev. Biol. 2015, 38, 2-6. [CrossRef]

82. Preston, J.E.; Joan Abbott, N.; Begley, D.J. Transcytosis of macromolecules at the blood-brain barrier. Adv. Pharmacol. 2014, 71, 147-163. [CrossRef]

83. Azevedo, F.A.; Carvalho, L.R.; Grinberg, L.T.; Farfel, J.M.; Ferretti, R.E.; Leite, R.E.; Jacob Filho, W.; Lent, R.; Herculano-Houzel, S. Equal numbers of neuronal and nonneuronal cells make the human brain an isometrically scaled-up primate brain. J. Comp. Neurol. 2009, 513, 532-541. [CrossRef] [PubMed]

84. Von Bartheld, C.S.; Bahney, J.; Herculano-Houzel, S. The search for true numbers of neurons and glial cells in the human brain: A review of 150 years of cell counting. J. Comp. Neurol. 2016, 524, 3865-3895. [CrossRef] [PubMed]

85. Chung, W.S.; Allen, N.J.; Eroglu, C. Astrocytes Control Synapse Formation, Function, and Elimination. Cold Spring Harb Perspect Biol. 2015, 7, a020370. [CrossRef] [PubMed]

86. Mathiisen, T.M.; Lehre, K.P.; Danbolt, N.C.; Ottersen, O.P. The perivascular astroglial sheath provides a complete covering of the brain microvessels: An electron microscopic 3D reconstruction. Glia 2010, 58, 1094-1103. [CrossRef]

87. Haddad-Tóvolli, R.; Dragano, N.R.V.; Ramalho, A.F.S.; Velloso, L.A. Development and Function of the Blood-Brain Barrier in the Context of Metabolic Control. Front. Neurosci. 2017, 11, 224. [CrossRef]

88. Simard, M.; Nedergaard, M. The neurobiology of glia in the context of water and ion homeostasis. Neuroscience 2004, 129, 877-896. [CrossRef]

89. Tao-Cheng, J.H.; Brightman, M.W. Development of membrane interactions between brain endothelial cells and astrocytes in vitro. Int. J. Dev. Neurosci. 1988, 6, 25-37. [CrossRef]

90. Broux, B.; Gowing, E.; Prat, A. Glial regulation of the blood-brain barrier in health and disease. Semin. Immunopathol. 2015, 37, 577-590. [CrossRef] 
91. Sims, D.E. The pericyte-A review. Tissue Cell 1986, 18, 153-174. [CrossRef]

92. Armulik, A.; Genové, G.; Betsholtz, C. Pericytes: Developmental, physiological, and pathological perspectives, problems, and promises. Dev. Cell 2011, 21, 193-215. [CrossRef]

93. Díaz-Flores, L.; Gutiérrez, R.; Madrid, J.F.; Varela, H.; Valladares, F.; Acosta, E.; Martín-Vasallo, P.; Díaz-Flores, L., Jr. Pericytes. Morphofunction, interactions and pathology in a quiescent and activated mesenchymal cell niche. Histol. Histopathol. 2009, 24, 909-969. [CrossRef] [PubMed]

94. Sims, D.; Horne, M.M.; Creighan, M.; Donald, A. Heterogeneity of pericyte populations in equine skeletal muscle and dermal microvessels: A quantitative study. Anat. Histol. Embryol. 1994, 23, 232-238. [CrossRef] [PubMed]

95. Armulik, A.; Genové, G.; Mäe, M.; Nisancioglu, M.H.; Wallgard, E.; Niaudet, C.; He, L.; Norlin, J.; Lindblom, P.; Strittmatter, K.; et al. Pericytes regulate the blood-brain barrier. Nature 2010, 468, 557-561. [CrossRef]

96. Nakagawa, S.; Deli, M.A.; Nakao, S.; Honda, M.; Hayashi, K.; Nakaoke, R.; Kataoka, Y.; Niwa, M. Pericytes from brain microvessels strengthen the barrier integrity in primary cultures of rat brain endothelial cells. Cell Mol. Neurobiol. 2007, 27, 687-694. [CrossRef] [PubMed]

97. Ginhoux, F.; Greter, M.; Leboeuf, M.; Nandi, S.; See, P.; Gokhan, S.; Mehler, M.F.; Conway, S.J.; Ng, L.G.; Stanley, E.R.; et al. Fate mapping analysis reveals that adult microglia derive from primitive macrophages. Science 2010, 330, 841-845. [CrossRef]

98. Dudvarski Stankovic, N.; Teodorczyk, M.; Ploen, R.; Zipp, F.; Schmidt, M.H.H. Microglia-blood vessel interactions: A double-edged sword in brain pathologies. Acta Neuropathol. 2016, 131, 347-363. [CrossRef]

99. Thurgur, H.; Pinteaux, E. Microglia in the Neurovascular Unit: Blood-Brain Barrier-microglia Interactions After Central Nervous System Disorders. Neuroscience 2019, 405, 55-67. [CrossRef]

100. Haruwaka, K.; Ikegami, A.; Tachibana, Y.; Ohno, N.; Konishi, H.; Hashimoto, A.; Matsumoto, M.; Kato, D.; Ono, R.; Kiyama, H.; et al. Dual microglia effects on blood brain barrier permeability induced by systemic inflammation. Nat. Commun. 2019, 10, 5816. [CrossRef]

101. Abbott, N.J.; Patabendige, A.A.; Dolman, D.E.; Yusof, S.R.; Begley, D.J. Structure and function of the blood-brain barrier. Neurobiol Dis 2010, 37, 13-25. [CrossRef]

102. Daneman, R.; Zhou, L.; Agalliu, D.; Cahoy, J.D.; Kaushal, A.; Barres, B.A. The mouse blood-brain barrier transcriptome: A new resource for understanding the development and function of brain endothelial cells. PLoS ONE 2010, 5, e13741. [CrossRef]

103. Munji, R.N.; Soung, A.L.; Weiner, G.A.; Sohet, F.; Semple, B.D.; Trivedi, A.; Gimlin, K.; Kotoda, M.; Korai, M.; Aydin, S.; et al. Profiling the mouse brain endothelial transcriptome in health and disease models reveals a core blood-brain barrier dysfunction module. Nat. Neurosci. 2019, 22, 1892-1902. [CrossRef] [PubMed]

104. Zeisel, A.; Muñoz-Manchado, A.B.; Codeluppi, S.; Lönnerberg, P.; La Manno, G.; Juréus, A.; Marques, S.; Munguba, H.; He, L.; Betsholtz, C.; et al. Brain structure. Cell types in the mouse cortex and hippocampus revealed by single-cell RNA-seq. Science 2015, 347, 1138-1142. [CrossRef] [PubMed]

105. Li, J.Y.; Boado, R.J.; Pardridge, W.M. Blood-brain barrier genomics. J. Cereb. Blood Flow Metab. 2001, 21, 61-68. [CrossRef] [PubMed]

106. Pardridge, W.M. Blood-brain barrier genomics and the use of endogenous transporters to cause drug penetration into the brain. Curr. Opin. Drug Discov. Devel. 2003, 6, 683-691. [PubMed]

107. Shusta, E.V. Blood-brain barrier genomics, proteomics, and new transporter discovery. NeuroRx 2005, 2, 151-161. [CrossRef] [PubMed]

108. Zhang, Y.; Chen, K.; Sloan, S.A.; Bennett, M.L.; Scholze, A.R.; O’Keeffe, S.; Phatnani, H.P.; Guarnieri, P.; Caneda, C.; Ruderisch, N.; et al. An RNA-sequencing transcriptome and splicing database of glia, neurons, and vascular cells of the cerebral cortex. J. Neurosci. 2014, 34, 11929-11947. [CrossRef]

109. Karamanos, Y.; Gosselet, F.; Dehouck, M.P.; Cecchelli, R. Blood-brain barrier proteomics: Towards the understanding of neurodegenerative diseases. Arch. Med. Res. 2014, 45, 730-737. [CrossRef]

110. Karamanos, Y.; Pottiez, G. Proteomics and the blood-brain barrier: How recent findings help drug development. Expert Rev. Proteomics 2016, 13, 251-258. [CrossRef]

111. Mäger, I.; Meyer, A.H.; Li, J.; Lenter, M.; Hildebrandt, T.; Leparc, G.; Wood, M.J.A. Targeting blood-brain- barrier transcytosis-Perspectives for drug delivery. Neuropharmacology 2017, 120, 4-7. [CrossRef]

112. Ohtsuki, S.; Hirayama, M.; Ito, S.; Uchida, Y.; Tachikawa, M.; Terasaki, T. Quantitative targeted proteomics for understanding the blood-brain barrier: Towards pharmacoproteomics. Expert Rev. Proteom. 2014, 11, 303-313. [CrossRef] 
113. Patching, S.G. Glucose Transporters at the Blood-Brain Barrier: Function, Regulation and Gateways for Drug Delivery. Mol. Neurobiol. 2017, 54, 1046-1077. [CrossRef] [PubMed]

114. Simpson, I.A.; Appel, N.M.; Hokari, M.; Oki, J.; Holman, G.D.; Maher, F.; Koehler-Stec, E.M.; Vannucci, S.J.; Smith, Q.R. Blood-brain barrier glucose transporter: Effects of hypo- and hyperglycemia revisited. J. Neurochem. 1999, 72, 238-247. [CrossRef] [PubMed]

115. Eyster, C.A.; Higginson, J.D.; Huebner, R.; Porat-Shliom, N.; Weigert, R.; Wu, W.W.; Shen, R.F.; Donaldson, J.G. Discovery of new cargo proteins that enter cells through clathrin-independent endocytosis. Traffic 2009, 10, 590-599. [CrossRef] [PubMed]

116. Riskin, A.; Nannegari, V.H.; Mond, Y. Acute effectors of GLUT1 glucose transporter subcellular targeting in CIT3 mouse mammary epithelial cells. Pediatr. Res. 2008, 63, 56-61. [CrossRef] [PubMed]

117. Johnsen, K.B.; Burkhart, A.; Thomsen, L.B.; Andresen, T.L.; Moos, T. Targeting the transferrin receptor for brain drug delivery. Prog. Neurobiol. 2019, 181, 101665. [CrossRef]

118. Johnsen, K.B.; Bak, M.; Kempen, P.J.; Melander, F.; Burkhart, A.; Thomsen, M.S.; Nielsen, M.S.; Moos, T.; Andresen, T.L. Antibody affinity and valency impact brain uptake of transferrin receptor-targeted gold nanoparticles. Theranostics 2018, 8, 3416-3436. [CrossRef]

119. Qian, Z.M.; Li, H.; Sun, H.; Ho, K. Targeted drug delivery via the transferrin receptor-mediated endocytosis pathway. Pharmacol. Rev. 2002, 54, 561-587. [CrossRef]

120. Kawabata, H.; Yang, R.; Hirama, T.; Vuong, P.T.; Kawano, S.; Gombart, A.F.; Koeffler, H.P. Molecular cloning of transferrin receptor 2. A new member of the transferrin receptor-like family. J. Biol. Chem. 1999, 274, 20826-20832. [CrossRef]

121. Kawabata, H.; Nakamaki, T.; Ikonomi, P.; Smith, R.D.; Germain, R.S.; Koeffler, H.P. Expression of transferrin receptor 2 in normal and neoplastic hematopoietic cells. Blood 2001, 98, 2714-2719. [CrossRef]

122. Herbison, C.E.; Thorstensen, K.; Chua, A.C.; Graham, R.M.; Leedman, P.; Olynyk, J.K.; Trinder, D. The role of transferrin receptor 1 and 2 in transferrin-bound iron uptake in human hepatoma cells. Am. J. Physiol. Cell Physiol. 2009, 297, C1567-C1575. [CrossRef]

123. Kawabata, H. Transferrin and transferrin receptors update. Free Radic. Biol. Med. 2019, 133, 46-54. [CrossRef] [PubMed]

124. Mills, E.; Dong, X.P.; Wang, F.; Xu, H. Mechanisms of brain iron transport: Insight into neurodegeneration and CNS disorders. Future Med. Chem. 2010, 2, 51-64. [CrossRef]

125. Dautry-Varsat, A.; Ciechanover, A.; Lodish, H.F. pH and the recycling of transferrin during receptor-mediated endocytosis. Proc. Natl. Acad. Sci. USA 1983, 80, 2258-2262. [CrossRef] [PubMed]

126. Bickel, U.; Yoshikawa, T.; Pardridge, W.M. Delivery of peptides and proteins through the blood-brain barrier. Adv. Drug Deliv. Rev. 2001, 46, 247-279. [CrossRef]

127. Skjørringe, T.; Burkhart, A.; Johnsen, K.B.; Moos, T. Divalent metal transporter 1 (DMT1) in the brain: Implications for a role in iron transport at the blood-brain barrier, and neuronal and glial pathology. Front. Mol. Neurosci. 2015, 8, 19. [CrossRef] [PubMed]

128. Johnsen, K.B.; Burkhart, A.; Melander, F.; Kempen, P.J.; Vejlebo, J.B.; Siupka, P.; Nielsen, M.S.; Andresen, T.L.; Moos, T. Targeting transferrin receptors at the blood-brain barrier improves the uptake of immunoliposomes and subsequent cargo transport into the brain parenchyma. Sci. Rep. 2017, 7, 10396. [CrossRef]

129. Lee, H.J.; Engelhardt, B.; Lesley, J.; Bickel, U.; Pardridge, W.M. Targeting rat anti-mouse transferrin receptor monoclonal antibodies through blood-brain barrier in mouse. J. Pharmacol. Exp. Ther. 2000, 292, 1048-1052.

130. Friden, P.M.; Olson, T.S.; Obar, R.; Walus, L.R.; Putney, S.D. Characterization, receptor mapping and blood-brain barrier transcytosis of antibodies to the human transferrin receptor. J. Pharmacol. Exp. Ther. 1996, $278,1491-1498$.

131. Jefferies, W.A.; Brandon, M.R.; Hunt, S.V.; Williams, A.F.; Gatter, K.C.; Mason, D.Y. Transferrin receptor on endothelium of brain capillaries. Nature 1984, 312, 162-163. [CrossRef]

132. Pardridge, W.M.; Buciak, J.L.; Friden, P.M. Selective transport of an anti-transferrin receptor antibody through the blood-brain barrier in vivo. J. Pharmacol. Exp. Ther. 1991, 259, 66-70.

133. Defesche, J.C. Low-density lipoprotein receptor-its structure, function, and mutations. Semin. Vasc. Med. 2004, 4, 5-11. [CrossRef] [PubMed]

134. Bathori, G.; Cervenak, L.; Karadi, I. Caveolae-an alternative endocytotic pathway for targeted drug delivery. Crit. Rev. Ther. Drug Carrier Syst. 2004, 21, 67-95. [CrossRef] [PubMed] 
135. Kiss, A.L.; Botos, E. Endocytosis via caveolae: Alternative pathway with distinct cellular compartments to avoid lysosomal degradation? J. Cell Mol. Med. 2009, 13, 1228-1237. [CrossRef]

136. Bertrand, N.; Grenier, P.; Mahmoudi, M.; Lima, E.M.; Appel, E.A.; Dormont, F.; Lim, J.M.; Karnik, R.; Langer, R.; Farokhzad, O.C. Mechanistic understanding of in vivo protein corona formation on polymeric nanoparticles and impact on pharmacokinetics. Nat. Commun. 2017, 8, 777. [CrossRef] [PubMed]

137. Capriotti, A.L.; Cavaliere, C.; Piovesana, S. Liposome protein corona characterization as a new approach in nanomedicine. Anal. Bioanal. Chem. 2019. [CrossRef] [PubMed]

138. Caracciolo, G.; Farokhzad, O.C.; Mahmoudi, M. Biological Identity of Nanoparticles In Vivo: Clinical Implications of the Protein Corona. Trends Biotechnol. 2017, 35, 257-264. [CrossRef]

139. Madathiparambil Visalakshan, R.; González García, L.E.; Benzigar, M.R.; Ghazaryan, A.; Simon, J.; Mierczynska-Vasilev, A.; Michl, T.D.; Vinu, A.; Mailänder, V.; Morsbach, S.; et al. The Influence of Nanoparticle Shape on Protein Corona Formation. Small 2020, 16, e2000285. [CrossRef]

140. Quagliarini, E.; Di Santo, R.; Palchetti, S.; Ferri, G.; Cardarelli, F.; Pozzi, D.; Caracciolo, G. Effect of Protein Corona on The Transfection Efficiency of Lipid-Coated Graphene Oxide-Based Cell Transfection Reagents. Pharmaceutics 2020, 12, 113. [CrossRef]

141. Richtering, W.; Alberg, I.; Zentel, R. Nanoparticles in the Biological Context: Surface Morphology and Protein Corona Formation. Small 2020, e2002162. [CrossRef]

142. Shadmani, P.; Mehrafrooz, B.; Montazeri, A.; Naghdabadi, R. Protein corona impact on nanoparticle-cell interactions: Toward an energy-based model of endocytosis. J. Phys. Condens. Matter. 2020, 32, 115101. [CrossRef]

143. Xiao, W.; Gao, H. The impact of protein corona on the behavior and targeting capability of nanoparticle-based delivery system. Int. J. Pharm. 2018, 552, 328-339. [CrossRef] [PubMed]

144. Yu, Q.; Zhao, L.; Guo, C.; Yan, B.; Su, G. Regulating Protein Corona Formation and Dynamic Protein Exchange by Controlling Nanoparticle Hydrophobicity. Front. Bioeng. Biotechnol. 2020, 8, 210. [CrossRef] [PubMed]

145. Ban, Z.; Yuan, P.; Yu, F.; Peng, T.; Zhou, Q.; Hu, X. Machine learning predicts the functional composition of the protein corona and the cellular recognition of nanoparticles. Proc. Natl. Acad. Sci. USA 2020, 117, 10492-10499. [CrossRef] [PubMed]

146. Francia, V.; Schiffelers, R.M.; Cullis, P.R.; Witzigmann, D. The Biomolecular Corona of Lipid Nanoparticles for Gene Therapy. Bioconjug. Chem. 2020. [CrossRef]

147. Salvati, A.; Pitek, A.S.; Monopoli, M.P.; Prapainop, K.; Bombelli, F.B.; Hristov, D.R.; Kelly, P.M.; Aberg, C.; Mahon, E.; Dawson, K.A. Transferrin-functionalized nanoparticles lose their targeting capabilities when a biomolecule corona adsorbs on the surface. Nat. Nanotechnol. 2013, 8, 137-143. [CrossRef]

148. Aoyama, M.; Hata, K.; Higashisaka, K.; Nagano, K.; Yoshioka, Y.; Tsutsumi, Y. Clusterin in the protein corona plays a key role in the stealth effect of nanoparticles against phagocytes. Biochem. Biophys. Res. Commun 2016, 480, 690-695. [CrossRef]

149. Caracciolo, G.; Pozzi, D.; Capriotti, A.L.; Cavaliere, C.; Piovesana, S.; Amenitsch, H.; Lagana, A. Lipid composition: A "key factor" for the rational manipulation of the liposome-protein corona by liposome design. RSC Advances 2015, 5, 5967-5975. [CrossRef]

150. Caracciolo, G.; Palchetti, S.; Colapicchioni, V.; Digiacomo, L.; Pozzi, D.; Capriotti, A.L.; La Barbera, G.; Lagana, A. Stealth effect of biomolecular corona on nanoparticle uptake by immune cells. Langmuir 2015, 31, 10764-10773. [CrossRef]

151. Chen, D.; Parayath, N.; Ganesh, S.; Wang, W.; Amiji, M. The role of apolipoprotein- and vitronectin-enriched protein corona on lipid nanoparticles for in vivo targeted delivery and transfection of oligonucleotides in murine tumor models. Nanoscale 2019, 11, 18806-18824. [CrossRef]

152. Lara, S.; Perez-Potti, A.; Herda, L.M.; Adumeau, L.; Dawson, K.A.; Yan, Y. Differential Recognition of Nanoparticle Protein Corona and Modified Low-Density Lipoprotein by Macrophage Receptor with Collagenous Structure. ACS Nano 2018, 12, 4930-4937. [CrossRef]

153. Schottler, S.; Becker, G.; Winzen, S.; Steinbach, T.; Mohr, K.; Landfester, K.; Mailander, V.; Wurm, F.R. Protein adsorption is required for stealth effect of poly(ethylene glycol)- and poly(phosphoester)-coated nanocarriers. Nat. Nanotechnol. 2016, 11, 372-377. [CrossRef] [PubMed]

154. Shen, L.; Tenzer, S.; Storck, W.; Hobernik, D.; Raker, V.K.; Fischer, K.; Decker, S.; Dzionek, A.; Krauthauser, S.; Diken, M.; et al. Protein corona-mediated targeting of nanocarriers to B cells allows redirection of allergic immune responses. J. Allergy Clin. Immunol. 2018. [CrossRef] [PubMed] 
155. Tian, X.H.; Lin, X.N.; Wei, F.; Feng, W.; Huang, Z.C.; Wang, P.; Ren, L.; Diao, Y. Enhanced brain targeting of temozolomide in polysorbate-80 coated polybutylcyanoacrylate nanoparticles. Int. J. Nanomed. 2011, 6, 445-452. [CrossRef]

156. Wilson, B.; Samanta, M.K.; Santhi, K.; Kumar, K.P.; Paramakrishnan, N.; Suresh, B. Poly(n-butylcyanoacrylate) nanoparticles coated with polysorbate 80 for the targeted delivery of rivastigmine into the brain to treat Alzheimer's disease. Brain Res. 2008, 1200, 159-168. [CrossRef] [PubMed]

157. Xu, N.; Gu, J.; Zhu, Y.; Wen, H.; Ren, Q.; Chen, J. Efficacy of intravenous amphotericin B-polybutylcyanoacrylate nanoparticles against cryptococcal meningitis in mice. Int. J. Nanomed. 2011, 6, 905-913. [CrossRef] [PubMed]

158. Demeule, M.; Régina, A.; Ché, C.; Poirier, J.; Nguyen, T.; Gabathuler, R.; Castaigne, J.P.; Béliveau, R. Identification and design of peptides as a new drug delivery system for the brain. J. Pharmacol. Exp. Ther. 2008, 324, 1064-1072. [CrossRef] [PubMed]

159. Demeule, M.; Currie, J.C.; Bertrand, Y.; Ché, C.; Nguyen, T.; Régina, A.; Gabathuler, R.; Castaigne, J.P.; Béliveau, R. Involvement of the low-density lipoprotein receptor-related protein in the transcytosis of the brain delivery vector angiopep-2. J. Neurochem. 2008, 106, 1534-1544. [CrossRef]

160. Gao, X.; Qian, J.; Zheng, S.; Xiong, Y.; Man, J.; Cao, B.; Wang, L.; Ju, S.; Li, C. Up-regulating blood brain barrier permeability of nanoparticles via multivalent effect. Pharm. Res. 2013, 30, 2538-2548. [CrossRef]

161. Gao, S.; Tian, H.; Xing, Z.; Zhang, D.; Guo, Y.; Guo, Z.; Zhu, X.; Chen, X. A non-viral suicide gene delivery system traversing the blood brain barrier for non-invasive glioma targeting treatment. J. Control Release 2016, 243, 357-369. [CrossRef]

162. Huang, S.; Li, J.; Han, L.; Liu, S.; Ma, H.; Huang, R.; Jiang, C. Dual targeting effect of Angiopep-2-modified, DNA-loaded nanoparticles for glioma. Biomaterials 2011, 32, 6832-6838. [CrossRef]

163. Huang, R.; Ma, H.; Guo, Y.; Liu, S.; Kuang, Y.; Shao, K.; Li, J.; Liu, Y.; Han, L.; Huang, S.; et al. Angiopep-conjugated nanoparticles for targeted long-term gene therapy of Parkinson's disease. Pharm. Res. 2013, 30, 2549-2559. [CrossRef] [PubMed]

164. Xin, H.; Sha, X.; Jiang, X.; Zhang, W.; Chen, L.; Fang, X. Anti-glioblastoma efficacy and safety of paclitaxel-loading Angiopep-conjugated dual targeting PEG-PCL nanoparticles. Biomaterials 2012, 33, 8167-8176. [CrossRef] [PubMed]

165. Kumthekar, P.; Tang, S.C.; Brenner, A.J.; Kesari, S.; Piccioni, D.E.; Anders, C.; Carrillo, J.; Chalasani, P.; Kabos, P.; Puhalla, S.; et al. ANG1005, a Brain-Penetrating Peptide-Drug Conjugate, Shows Activity in Patients with Breast Cancer with Leptomeningeal Carcinomatosis and Recurrent Brain Metastases. Clin. Cancer Res. 2020, 26, 2789-2799. [CrossRef] [PubMed]

166. Kurzrock, R.; Gabrail, N.; Chandhasin, C.; Moulder, S.; Smith, C.; Brenner, A.; Sankhala, K.; Mita, A.; Elian, K.; Bouchard, D.; et al. Safety, pharmacokinetics, and activity of GRN1005, a novel conjugate of angiopep-2, a peptide facilitating brain penetration, and paclitaxel, in patients with advanced solid tumors. Mol. Cancer Ther. 2012, 11, 308-316. [CrossRef]

167. Drappatz, J.; Brenner, A.; Wong, E.T.; Eichler, A.; Schiff, D.; Groves, M.D.; Mikkelsen, T.; Rosenfeld, S.; Sarantopoulos, J.; Meyers, C.A.; et al. Phase I study of GRN1005 in recurrent malignant glioma. Clin. Cancer Res. 2013, 19, 1567-1576. [CrossRef]

168. Butcher, E.C. Leukocyte-endothelial cell recognition: Three (or more) steps to specificity and diversity. Cell 1991, 67, 1033-1036. [CrossRef]

169. Kunkel, E.J.; Butcher, E.C. Chemokines and the tissue-specific migration of lymphocytes. Immunity 2002, 16, 1-4. [CrossRef]

170. Medawar, P.B. Immunity to homologous grafted skin; the fate of skin homografts transplanted to the brain, to subcutaneous tissue, and to the anterior chamber of the eye. Br. J. Exp. Pathol. 1948, 29, 58-69.

171. Kleine, T.O.; Benes, L. Immune surveillance of the human central nervous system (CNS): Different migration pathways of immune cells through the blood-brain barrier and blood-cerebrospinal fluid barrier in healthy persons. Cytometry A 2006, 69, 147-151. [CrossRef]

172. Ransohoff, R.M.; Kivisäkk, P.; Kidd, G. Three or more routes for leukocyte migration into the central nervous system. Nat. Rev. Immunol. 2003, 3, 569-581. [CrossRef]

173. Greenhalgh, A.D.; David, S.; Bennett, F.C. Immune cell regulation of glia during CNS injury and disease. Nat. Rev. Neurosci. 2020, 21, 139-152. [CrossRef] [PubMed] 
174. Engelhardt, B.; Vajkoczy, P.; Weller, R.O. The movers and shapers in immune privilege of the CNS. Nat. Immunol. 2017, 18, 123-131. [CrossRef] [PubMed]

175. Wilson, E.H.; Weninger, W.; Hunter, C.A. Trafficking of immune cells in the central nervous system. J. Clin. Investig. 2010, 120, 1368-1379. [CrossRef] [PubMed]

176. Engelhardt, B.; Ransohoff, R.M. The ins and outs of T-lymphocyte trafficking to the CNS: Anatomical sites and molecular mechanisms. Trends Immunol. 2005, 26, 485-495. [CrossRef] [PubMed]

177. Marchetti, L.; Engelhardt, B. Immune cell trafficking across the blood-brain barrier in the absence and presence of neuroinflammation. Vasc. Biol. 2020, 2, H1-H18. [CrossRef] [PubMed]

178. Carrithers, M.D.; Visintin, I.; Kang, S.J.; Janeway, C.A., Jr. Differential adhesion molecule requirements for immune surveillance and inflammatory recruitment. Brain 2000, 123 Pt 6, 1092-1101. [CrossRef]

179. Steiner, O.; Coisne, C.; Cecchelli, R.; Boscacci, R.; Deutsch, U.; Engelhardt, B.; Lyck, R. Differential roles for endothelial ICAM-1, ICAM-2, and VCAM-1 in shear-resistant T cell arrest, polarization, and directed crawling on blood-brain barrier endothelium. J. Immunol. 2010, 185, 4846-4855. [CrossRef]

180. Abadier, M.; Haghayegh Jahromi, N.; Cardoso Alves, L.; Boscacci, R.; Vestweber, D.; Barnum, S.; Deutsch, U.; Engelhardt, B.; Lyck, R. Cell surface levels of endothelial ICAM-1 influence the transcellular or paracellular T-cell diapedesis across the blood-brain barrier. Eur. J. Immunol. 2015, 45, 1043-1058. [CrossRef]

181. Gorina, R.; Lyck, R.; Vestweber, D.; Engelhardt, B. $\beta 2$ integrin-mediated crawling on endothelial ICAM-1 and ICAM-2 is a prerequisite for transcellular neutrophil diapedesis across the inflamed blood-brain barrier. J. Immunol. 2014, 192, 324-337. [CrossRef]

182. Marcos-Contreras, O.A.; Brenner, J.S.; Kiseleva, R.Y.; Zuluaga-Ramirez, V.; Greineder, C.F.; Villa, C.H.; Hood, E.D.; Myerson, J.W.; Muro, S.; Persidsky, Y.; et al. Combining vascular targeting and the local first pass provides 100-fold higher uptake of ICAM-1-targeted vs untargeted nanocarriers in the inflamed brain. J. Control. Release 2019, 301, 54-61. [CrossRef]

183. Hsu, J.; Rappaport, J.; Muro, S. Specific binding, uptake, and transport of ICAM-1-targeted nanocarriers across endothelial and subendothelial cell components of the blood-brain barrier. Pharm. Res. 2014, 31, 1855-1866. [CrossRef] [PubMed]

184. Marcos-Contreras, O.A.; Greineder, C.F.; Kiseleva, R.Y.; Parhiz, H.; Walsh, L.R.; Zuluaga-Ramirez, V.; Myerson, J.W.; Hood, E.D.; Villa, C.H.; Tombacz, I.; et al. Selective targeting of nanomedicine to inflamed cerebral vasculature to enhance the blood-brain barrier. Proc. Natl. Acad. Sci. USA 2020, 117, 3405-3414. [CrossRef] [PubMed]

185. Manthe, R.L.; Loeck, M.; Bhowmick, T.; Solomon, M.; Muro, S. Intertwined mechanisms define transport of anti-ICAM nanocarriers across the endothelium and brain delivery of a therapeutic enzyme. J. Control. Release 2020, 324, 181-193. [CrossRef] [PubMed]

186. Arima, Y.; Kamimura, D.; Sabharwal, L.; Yamada, M.; Bando, H.; Ogura, H.; Atsumi, T.; Murakami, M. Regulation of immune cell infiltration into the CNS by regional neural inputs explained by the gate theory. Mediators Inflamm. 2013, 2013, 898165. [CrossRef]

187. Arima, Y.; Harada, M.; Kamimura, D.; Park, J.H.; Kawano, F.; Yull, F.E.; Kawamoto, T.; Iwakura, Y.; Betz, U.A.; Márquez, G.; et al. Regional neural activation defines a gateway for autoreactive $\mathrm{T}$ cells to cross the blood-brain barrier. Cell 2012, 148, 447-457. [CrossRef]

188. Kamimura, D.; Yamada, M.; Harada, M.; Sabharwal, L.; Meng, J.; Bando, H.; Ogura, H.; Atsumi, T.; Arima, Y.; Murakami, M. The gateway theory: Bridging neural and immune interactions in the CNS. Front. Neurosci. 2013, 7, 204. [CrossRef]

189. Ogura, H.; Arima, Y.; Kamimura, D.; Murakami, M. The gateway theory: How regional neural activation creates a gateway for immune cells via an inflammation amplifier. Biomed. J. 2013, 36, 269-273. [CrossRef]

190. Kamimura, D.; Murakami, M. Neural stimulations regulate the infiltration of immune cells into the CNS. J. Intern Med. 2019, 286, 259-267. [CrossRef]

191. Sabharwal, L.; Kamimura, D.; Meng, J.; Bando, H.; Ogura, H.; Nakayama, C.; Jiang, J.J.; Kumai, N.; Suzuki, H.; Atsumi, T.; et al. The Gateway Reflex, which is mediated by the inflammation amplifier, directs pathogenic immune cells into the CNS. J. Biochem. 2014, 156, 299-304. [CrossRef]

192. Stofkova, A.; Murakami, M. Neural activity regulates autoimmune diseases through the gateway reflex. Bioelectron. Med. 2019, 5, 14. [CrossRef]

193. Tanaka, Y.; Arima, Y.; Kamimura, D.; Murakami, M. The Gateway Reflex, a Novel Neuro-Immune Interaction for the Regulation of Regional Vessels. Front. Immunol. 2017, 8, 1321. [CrossRef] [PubMed] 
194. Herrmann, A.K.; Grimm, D. High-Throughput Dissection of AAV-Host Interactions: The Fast and the Curious. J. Mol. Biol. 2018, 430, 2626-2640. [CrossRef] [PubMed]

195. Deverman, B.E.; Pravdo, P.L.; Simpson, B.P.; Kumar, S.R.; Chan, K.Y.; Banerjee, A.; Wu, W.L.; Yang, B.; Huber, N.; Pasca, S.P.; et al. Cre-dependent selection yields AAV variants for widespread gene transfer to the adult brain. Nat. Biotechnol. 2016, 34, 204-209. [CrossRef] [PubMed]

196. Matsuzaki, Y.; Konno, A.; Mochizuki, R.; Shinohara, Y.; Nitta, K.; Okada, Y.; Hirai, H. Intravenous administration of the adeno-associated virus-PHP.B capsid fails to upregulate transduction efficiency in the marmoset brain. Neurosci. Lett. 2018, 665, 182-188. [CrossRef]

197. Liguore, W.A.; Domire, J.S.; Button, D.; Wang, Y.; Dufour, B.D.; Srinivasan, S.; McBride, J.L. AAV-PHP.B Administration Results in a Differential Pattern of CNS Biodistribution in Non-human Primates Compared with Mice. Mol. Ther. 2019, 27, 2018-2037. [CrossRef]

198. Huang, Q.; Chan, K.Y.; Tobey, I.G.; Chan, Y.A.; Poterba, T.; Boutros, C.L.; Balazs, A.B.; Daneman, R.; Bloom, J.M.; Seed, C.; et al. Delivering genes across the blood-brain barrier: LY6A, a novel cellular receptor for AAV-PHP.B capsids. PLOS ONE 2019, 14, e0225206. [CrossRef]

199. Batista, A.R.; King, O.D.; Reardon, C.P.; Davis, C.; Shankaracharya; Philip, V.; Gray-Edwards, H.; Aronin, N.; Lutz, C.; Landers, J.; et al. Ly6a Differential Expression in Blood-Brain Barrier Is Responsible for Strain Specific Central Nervous System Transduction Profile of AAV-PHP.B. Hum. Gene Ther. 2020, 31, 90-102. [CrossRef]

200. Hordeaux, J.; Yuan, Y.; Clark, P.M.; Wang, Q.; Martino, R.A.; Sims, J.J.; Bell, P.; Raymond, A.; Stanford, W.L.; Wilson, J.M. The GPI-Linked Protein LY6A Drives AAV-PHP.B Transport across the Blood-Brain Barrier. Mol. Ther. 2019, 27, 912-921. [CrossRef]

201. Yamazaki, Y.; Kanekiyo, T. Blood-Brain Barrier Dysfunction and the Pathogenesis of Alzheimer's Disease. Int. J. Mol. Sci. 2017, 18, 1965. [CrossRef]

202. Oku, N. Innovations in Liposomal DDS Technology and Its Application for the Treatment of Various Diseases. Biol. Pharm. Bull. 2017, 40,119-127. [CrossRef]

203. Deane, R.; Wu, Z.; Sagare, A.; Davis, J.; Du Yan, S.; Hamm, K.; Xu, F.; Parisi, M.; LaRue, B.; Hu, H.W.; et al. LRP/amyloid beta-peptide interaction mediates differential brain efflux of Abeta isoforms. Neuron 2004, 43, 333-344. [CrossRef] [PubMed]

204. Vogelgesang, S.; Cascorbi, I.; Schroeder, E.; Pahnke, J.; Kroemer, H.K.; Siegmund, W.; Kunert-Keil, C.; Walker, L.C.; Warzok, R.W. Deposition of Alzheimer's beta-amyloid is inversely correlated with P-glycoprotein expression in the brains of elderly non-demented humans. Pharmacogenetics 2002, 12, 535-541. [CrossRef] [PubMed]

205. Carrano, A.; Hoozemans, J.J.; van der Vies, S.M.; van Horssen, J.; de Vries, H.E.; Rozemuller, A.J. Neuroinflammation and blood-brain barrier changes in capillary amyloid angiopathy. Neurodegener. Dis. 2012, 10, 329-331. [CrossRef] [PubMed]

206. Waubant, E. Biomarkers indicative of blood-brain barrier disruption in multiple sclerosis. Dis. Markers 2006, 22, 235-244. [CrossRef]

207. Chen, X.; Lan, X.; Roche, I.; Liu, R.; Geiger, J.D. Caffeine protects against MPTP-induced blood-brain barrier dysfunction in mouse striatum. J. Neurochem. 2008, 107, 1147-1157. [CrossRef]

208. Gu, X.L.; Long, C.X.; Sun, L.; Xie, C.; Lin, X.; Cai, H. Astrocytic expression of Parkinson's disease-related A53T alpha-synuclein causes neurodegeneration in mice. Mol. Brain 2010, 3, 12. [CrossRef]

209. McCall, A.L.; Van Bueren, A.M.; Nipper, V.; Moholt-Siebert, M.; Downes, H.; Lessov, N. Forebrain ischemia increases GLUT1 protein in brain microvessels and parenchyma. J. Cereb. Blood Flow Metab. 1996, 16, 69-76. [CrossRef]

210. Haley, M.J.; Lawrence, C.B. The blood-brain barrier after stroke: Structural studies and the role of transcytotic vesicles. J. Cereb. Blood Flow Metab. 2017, 37, 456-470. [CrossRef]

211. Knowland, D.; Arac, A.; Sekiguchi, K.J.; Hsu, M.; Lutz, S.E.; Perrino, J.; Steinberg, G.K.; Barres, B.A.; Nimmerjahn, A.; Agalliu, D. Stepwise recruitment of transcellular and paracellular pathways underlies blood-brain barrier breakdown in stroke. Neuron 2014, 82, 603-617. [CrossRef]

212. van Tellingen, O.; Yetkin-Arik, B.; de Gooijer, M.C.; Wesseling, P.; Wurdinger, T.; de Vries, H.E. Overcoming the blood-brain tumor barrier for effective glioblastoma treatment. Drug Resist. Updat. 2015, 19, 1-12. [CrossRef] 
213. Aronica, E.; Gorter, J.A.; Redeker, S.; van Vliet, E.A.; Ramkema, M.; Scheffer, G.L.; Scheper, R.J.; van der Valk, P.; Leenstra, S.; Baayen, J.C.; et al. Localization of breast cancer resistance protein (BCRP) in microvessel endothelium of human control and epileptic brain. Epilepsia 2005, 46, 849-857. [CrossRef] [PubMed]

214. Grimm, D.; Zolotukhin, S. E Pluribus Unum: 50 Years of Research, Millions of Viruses, and One Goal-Tailored Acceleration of AAV Evolution. Mol. Ther. 2015, 23, 1819-1831. [CrossRef] [PubMed]

215. Lee, E.J.; Guenther, C.M.; Suh, J. Adeno-Associated Virus (AAV) Vectors: Rational Design Strategies for Capsid Engineering. Curr. Opin. Biomed. Eng. 2018, 7, 58-63. [CrossRef] [PubMed]

216. Foust, K.D.; Nurre, E.; Montgomery, C.L.; Hernandez, A.; Chan, C.M.; Kaspar, B.K. Intravascular AAV9 preferentially targets neonatal neurons and adult astrocytes. Nat. Biotechnol. 2009, 27, 59-65. [CrossRef]

217. Iida, A.; Takino, N.; Miyauchi, H.; Shimazaki, K.; Muramatsu, S. Systemic delivery of tyrosine-mutant AAV vectors results in robust transduction of neurons in adult mice. Biomed. Res. Int. 2013, 2013, 974819. [CrossRef]

218. Choudhury, S.R.; Fitzpatrick, Z.; Harris, A.F.; Maitland, S.A.; Ferreira, J.S.; Zhang, Y.; Ma, S.; Sharma, R.B.; Gray-Edwards, H.L.; Johnson, J.A.; et al. In Vivo Selection Yields AAV-B1 Capsid for Central Nervous System and Muscle Gene Therapy. Mol. Ther. 2016, 24, 1247-1257. [CrossRef]

219. Choudhury, S.R.; Harris, A.F.; Cabral, D.J.; Keeler, A.M.; Sapp, E.; Ferreira, J.S.; Gray-Edwards, H.L.; Johnson, J.A.; Johnson, A.K.; Su, Q.; et al. Widespread Central Nervous System Gene Transfer and Silencing After Systemic Delivery of Novel AAV-AS Vector. Mol. Ther. 2016, 24, 726-735. [CrossRef]

220. Saraiva, J.; Nobre, R.J.; Pereira de Almeida, L. Gene therapy for the CNS using AAVs: The impact of systemic delivery by AAV9. J. Control. Release 2016, 241, 94-109. [CrossRef]

221. Murlidharan, G.; Samulski, R.J.; Asokan, A. Biology of adeno-associated viral vectors in the central nervous system. Front. Mol. Neurosci. 2014, 7, 76. [CrossRef]

222. Duque, S.; Joussemet, B.; Riviere, C.; Marais, T.; Dubreil, L.; Douar, A.M.; Fyfe, J.; Moullier, P.; Colle, M.A.; Barkats, M. Intravenous administration of self-complementary AAV9 enables transgene delivery to adult motor neurons. Mol. Ther. 2009, 17, 1187-1196. [CrossRef]

223. Körbelin, J.; Dogbevia, G.; Michelfelder, S.; Ridder, D.A.; Hunger, A.; Wenzel, J.; Seismann, H.; Lampe, M.; Bannach, J.; Pasparakis, M.; et al. A brain microvasculature endothelial cell-specific viral vector with the potential to treat neurovascular and neurological diseases. EMBO Mol. Med. 2016, 8, 609-625. [CrossRef] [PubMed]

224. Griffin, J.M.; Fackelmeier, B.; Fong, D.M.; Mouravlev, A.; Young, D.; O'Carroll, S.J. Astrocyte-selective AAV gene therapy through the endogenous GFAP promoter results in robust transduction in the rat spinal cord following injury. Gene Ther. 2019, 26, 198-210. [CrossRef] [PubMed]

225. Vagner, T.; Dvorzhak, A.; Wójtowicz, A.M.; Harms, C.; Grantyn, R. Systemic application of AAV vectors targeting GFAP-expressing astrocytes in Z-Q175-KI Huntington's disease mice. Mol. Cell Neurosci. 2016, 77, 76-86. [CrossRef] [PubMed]

226. Ravindra Kumar, S.; Miles, T.F.; Chen, X.; Brown, D.; Dobreva, T.; Huang, Q.; Ding, X.; Luo, Y.; Einarsson, P.H.; Greenbaum, A.; et al. Multiplexed Cre-dependent selection yields systemic AAVs for targeting distinct brain cell types. Nat. Methods 2020, 17, 541-550. [CrossRef] [PubMed]

227. D'Amico, A.; Mercuri, E.; Tiziano, F.D.; Bertini, E. Spinal muscular atrophy. Orphanet. J. Rare Dis. $2011,6,71$. [CrossRef] [PubMed]

228. Parente, V.; Corti, S. Advances in spinal muscular atrophy therapeutics. Ther. Adv. Neurol. Disord. $2018,11$. [CrossRef]

229. Dabbous, O.; Maru, B.; Jansen, J.P.; Lorenzi, M.; Cloutier, M.; Guérin, A.; Pivneva, I.; Wu, E.Q.; Arjunji, R.; Feltner, D.; et al. Survival, Motor Function, and Motor Milestones: Comparison of AVXS-101 Relative to Nusinersen for the Treatment of Infants with Spinal Muscular Atrophy Type 1. Adv. Ther. 2019, 36, 1164-1176. [CrossRef]

230. Hinderer, C.; Katz, N.; Buza, E.L.; Dyer, C.; Goode, T.; Bell, P.; Richman, L.K.; Wilson, J.M. Severe Toxicity in Nonhuman Primates and Piglets Following High-Dose Intravenous Administration of an Adeno-Associated Virus Vector Expressing Human SMN. Hum. Gene Ther. 2018, 29, 285-298. [CrossRef]

231. Note: Zolgensma data manipulation. Med. Lett. Drugs Ther. 2019, 61, 129.

232. Parks, W.P.; Boucher, D.W.; Melnick, J.L.; Taber, L.H.; Yow, M.D. Seroepidemiological and ecological studies of the adenovirus-associated satellite viruses. Infect. Immun. 1970, 2, 716-722. [CrossRef] 
233. Mimuro, J.; Mizukami, H.; Shima, M.; Matsushita, T.; Taki, M.; Muto, S.; Higasa, S.; Sakai, M.; Ohmori, T.; Madoiwa, S.; et al. The prevalence of neutralizing antibodies against adeno-associated virus capsids is reduced in young Japanese individuals. J. Med. Virol. 2014, 86, 1990-1997. [CrossRef] [PubMed]

234. Mingozzi, F.; Chen, Y.; Edmonson, S.C.; Zhou, S.; Thurlings, R.M.; Tak, P.P.; High, K.A.; Vervoordeldonk, M.J. Prevalence and pharmacological modulation of humoral immunity to AAV vectors in gene transfer to synovial tissue. Gene Ther. 2013, 20, 417-424. [CrossRef] [PubMed]

235. Louis Jeune, V.; Joergensen, J.A.; Hajjar, R.J.; Weber, T. Pre-existing anti-adeno-associated virus antibodies as a challenge in AAV gene therapy. Hum. Gene Ther. Methods 2013, 24, 59-67. [CrossRef] [PubMed]

236. Manno, C.S.; Pierce, G.F.; Arruda, V.R.; Glader, B.; Ragni, M.; Rasko, J.J.; Ozelo, M.C.; Hoots, K.; Blatt, P.; Konkle, B.; et al. Successful transduction of liver in hemophilia by AAV-Factor IX and limitations imposed by the host immune response. Nat. Med. 2006, 12, 342-347. [CrossRef]

237. Mimuro, J.; Mizukami, H.; Hishikawa, S.; Ikemoto, T.; Ishiwata, A.; Sakata, A.; Ohmori, T.; Madoiwa, S.; Ono, F.; Ozawa, K.; et al. Minimizing the inhibitory effect of neutralizing antibody for efficient gene expression in the liver with adeno-associated virus 8 vectors. Mol. Ther. 2013, 21, 318-323. [CrossRef]

238. Duan, D. Micro-Dystrophin Gene Therapy Goes Systemic in Duchenne Muscular Dystrophy Patients. Hum. Gene Ther. 2018, 29, 733-736. [CrossRef]

239. Shankar, R.; Joshi, M.; Pathak, K. Lipid Nanoparticles: A Novel Approach for Brain Targeting. Pharm. Nanotechnol. 2018, 6, 81-93. [CrossRef]

240. Agrawal, M.; Saraf, S.; Dubey, S.K.; Puri, A.; Patel, R.J.; Ajazuddin; Ravichandiran, V.; Murty, U.S.; Alexander, A. Recent strategies and advances in the fabrication of nano lipid carriers and their application towards brain targeting. J. Control. Release 2020, 321, 372-415. [CrossRef]

241. Lu, Y.; Jiang, C. Brain-Targeted Polymers for Gene Delivery in the Treatment of Brain Diseases. Top Curr. Chem. (Cham.) 2017, 375, 48. [CrossRef]

242. Fu, C.; Xiang, Y.; Li, X.; Fu, A. Targeted transport of nanocarriers into brain for theranosis with rabies virus glycoprotein-derived peptide. Mater. Sci. Eng. C. Mater. Biol. Appl. 2018, 87, 155-166. [CrossRef]

243. Oswald, M.; Geissler, S.; Goepferich, A. Targeting the Central Nervous System (CNS): A Review of Rabies Virus-Targeting Strategies. Mol. Pharm. 2017, 14, 2177-2196. [CrossRef] [PubMed]

244. Fisher, C.R.; Streicker, D.G.; Schnell, M.J. The spread and evolution of rabies virus: Conquering new frontiers. Nat. Rev. Microbiol. 2018, 16, 241-255. [CrossRef] [PubMed]

245. Schnell, M.J.; McGettigan, J.P.; Wirblich, C.; Papaneri, A. The cell biology of rabies virus: Using stealth to reach the brain. Nat. Rev. Microbiol. 2010, 8, 51-61. [CrossRef] [PubMed]

246. Al-Obaidi, M.M.J.; Bahadoran, A.; Wang, S.M.; Manikam, R.; Raju, C.S.; Sekaran, S.D. Disruption of the blood brain barrier is vital property of neurotropic viral infection of the central nervous system. Acta Virol. 2018, 62, 16-27. [CrossRef]

247. Preuss, M.A.; Faber, M.L.; Tan, G.S.; Bette, M.; Dietzschold, B.; Weihe, E.; Schnell, M.J. Intravenous inoculation of a bat-associated rabies virus causes lethal encephalopathy in mice through invasion of the brain via neurosecretory hypothalamic fibers. PLoS Pathog. 2009, 5, e1000485. [CrossRef]

248. Fu, A.; Wang, Y.; Zhan, L.; Zhou, R. Targeted delivery of proteins into the central nervous system mediated by rabies virus glycoprotein-derived peptide. Pharm. Res. 2012, 29, 1562-1569. [CrossRef]

249. Fu, A.; Zhang, M.; Gao, F.; Xu, X.; Chen, Z. A novel peptide delivers plasmids across blood-brain barrier into neuronal cells as a single-component transfer vector. PLoS ONE 2013, 8, e59642. [CrossRef]

250. Zou, Z.; Sun, Z.; Li, P.; Feng, T.; Wu, S. Cre Fused with RVG Peptide Mediates Targeted Genome Editing in Mouse Brain Cells In Vivo. Int. J. Mol. Sci. 2016, 17, 2104. [CrossRef]

251. Capriotti, A.; Piovesana, S.; Zenezini Chiozzi, R.; Montone, C.M.; Bossi, A.M.; Laganà, A. Does the protein corona take over the selectivity of molecularly imprinted nanoparticles? The biological challenges to recognition. J. Proteom. 2020, 219, 103736. [CrossRef]

252. Rampado, R.; Crotti, S.; Caliceti, P.; Pucciarelli, S.; Agostini, M. Recent Advances in Understanding the Protein Corona of Nanoparticles and in the Formulation of: "Stealthy" Nanomaterials. Front. Bioeng. Biotechnol. 2020, 8, 166. [CrossRef]

253. Zhang, Y.; Wu, J.L.Y.; Lazarovits, J.; Chan, W.C.W. An Analysis of the Binding Function and Structural Organization of the Protein Corona. J. Am. Chem. Soc. 2020, 142, 8827-8836. [CrossRef]

254. Chen, D.; Ganesh, S.; Wang, W.; Amiji, M. Protein Corona-Enabled Systemic Delivery and Targeting of Nanoparticles. AAPS J. 2020, 22, 83. [CrossRef] 
255. Kelly, P.M.; Åberg, C.; Polo, E.; O’Connell, A.; Cookman, J.; Fallon, J.; Krpetić, Ž.; Dawson, K.A. Mapping protein binding sites on the biomolecular corona of nanoparticles. Nat. Nanotechnol. 2015, 10, 472-479. [CrossRef]

256. Mirshafiee, V.; Kim, R.; Park, S.; Mahmoudi, M.; Kraft, M.L. Impact of protein pre-coating on the protein corona composition and nanoparticle cellular uptake. Biomaterials 2016, 75, 295-304. [CrossRef]

257. Cheng, Z.; Al Zaki, A.; Hui, J.Z.; Muzykantov, V.R.; Tsourkas, A. Multifunctional nanoparticles: Cost versus benefit of adding targeting and imaging capabilities. Science 2012, 338, 903-910. [CrossRef]

258. Vyas, S.P.; Sihorkar, V. Endogenous carriers and ligands in non-immunogenic site-specific drug delivery. Adv. Drug Deliv. Rev. 2000, 43, 101-164. [CrossRef]

259. Burgess, A.; Hynynen, K. Noninvasive and targeted drug delivery to the brain using focused ultrasound. ACS Chem. Neurosci. 2013, 4, 519-526. [CrossRef]

260. Burgess, A.; Hynynen, K. Drug delivery across the blood-brain barrier using focused ultrasound. Expert Opin. Drug Deliv. 2014, 11, 711-721. [CrossRef]

261. Burgess, A.; Shah, K.; Hough, O.; Hynynen, K. Focused ultrasound-mediated drug delivery through the blood-brain barrier. Expert Rev. Neurother. 2015, 15, 477-491. [CrossRef]

262. Fisher, D.G.; Price, R.J. Recent Advances in the Use of Focused Ultrasound for Magnetic Resonance Image-Guided Therapeutic Nanoparticle Delivery to the Central Nervous System. Front. Pharmacol. 2019, 10, 1348. [CrossRef]

263. Meairs, S. Facilitation of Drug Transport across the Blood-Brain Barrier with Ultrasound and Microbubbles. Pharmaceutics 2015, 7, 275-293. [CrossRef] [PubMed]

264. Endo-Takahashi, Y.; Negishi, Y. Microbubbles and Nanobubbles with Ultrasound for Systemic Gene Delivery. Pharmaceutics 2020, 12, 964. [CrossRef] [PubMed]

265. Fan, C.H.; Ting, C.Y.; Lin, C.Y.; Chan, H.L.; Chang, Y.C.; Chen, Y.Y.; Liu, H.L.; Yeh, C.K. Noninvasive, Targeted, and Non-Viral Ultrasound-Mediated GDNF-Plasmid Delivery for Treatment of Parkinson's Disease. Sci. Rep. 2016, 6, 19579. [CrossRef] [PubMed]

266. Fan, C.H.; Lin, C.Y.; Liu, H.L.; Yeh, C.K. Ultrasound targeted CNS gene delivery for Parkinson's disease treatment. J. Control. Release 2017, 261, 246-262. [CrossRef] [PubMed]

267. Lin, C.Y.; Hsieh, H.Y.; Chen, C.M.; Wu, S.R.; Tsai, C.H.; Huang, C.Y.; Hua, M.Y.; Wei, K.C.; Yeh, C.K.; Liu, H.L. Non-invasive, neuron-specific gene therapy by focused ultrasound-induced blood-brain barrier opening in Parkinson's disease mouse model. J. Control. Release 2016, 235, 72-81. [CrossRef] [PubMed]

268. Lin, C.Y.; Tsai, C.H.; Feng, L.Y.; Chai, W.Y.; Lin, C.J.; Huang, C.Y.; Wei, K.C.; Yeh, C.K.; Chen, C.M.; Liu, H.L. Focused ultrasound-induced blood brain-barrier opening enhanced vascular permeability for GDNF delivery in Huntington's disease mouse model. Brain Stimul. 2019, 12, 1143-1150. [CrossRef] [PubMed]

269. Mead, B.P.; Kim, N.; Miller, G.W.; Hodges, D.; Mastorakos, P.; Klibanov, A.L.; Mandell, J.W.; Hirsh, J.; Suk, J.S.; Hanes, J.; et al. Novel Focused Ultrasound Gene Therapy Approach Noninvasively Restores Dopaminergic Neuron Function in a Rat Parkinson's Disease Model. Nano Lett. 2017, 17, 3533-3542. [CrossRef]

270. Bilang-Bleuel, A.; Revah, F.; Colin, P.; Locquet, I.; Robert, J.J.; Mallet, J.; Horellou, P. Intrastriatal injection of an adenoviral vector expressing glial-cell-line-derived neurotrophic factor prevents dopaminergic neuron degeneration and behavioral impairment in a rat model of Parkinson disease. Proc. Natl. Acad. Sci. USA 1997, 94, 8818-8823. [CrossRef]

271. Tomac, A.; Lindqvist, E.; Lin, L.F.; Ogren, S.O.; Young, D.; Hoffer, B.J.; Olson, L. Protection and repair of the nigrostriatal dopaminergic system by GDNF in vivo. Nature 1995, 373, 335-339. [CrossRef]

272. Lin, L.F.; Doherty, D.H.; Lile, J.D.; Bektesh, S.; Collins, F. GDNF: A glial cell line-derived neurotrophic factor for midbrain dopaminergic neurons. Science 1993, 260, 1130-1132. [CrossRef]

273. Gash, D.M.; Zhang, Z.; Ovadia, A.; Cass, W.A.; Yi, A.; Simmerman, L.; Russell, D.; Martin, D.; Lapchak, P.A.; Collins, F.; et al. Functional recovery in parkinsonian monkeys treated with GDNF. Nature 1996, 380, $252-255$. [CrossRef] [PubMed]

274. Zhang, L.; Han, L.; Qin, J.; Lu, W.; Wang, J. The use of borneol as an enhancer for targeting aprotinin-conjugated PEG-PLGA nanoparticles to the brain. Pharm. Res. 2013, 30, 2560-2572. [CrossRef] [PubMed]

275. Wu, T.; Zhang, A.; Lu, H.; Cheng, Q. The Role and Mechanism of Borneol to Open the Blood-Brain Barrier. Integr. Cancer. Ther. 2018, 17, 806-812. [CrossRef] [PubMed] 
276. Garg, P.; Pandey, S.; Seonwoo, H.; Yeom, S.; Choung, Y.H.; Cho, C.S.; Choung, P.H.; Hoon Chung, J. Hyperosmotic polydixylitol for crossing the blood brain barrier and efficient nucleic acid delivery. Chem. Commun. (Camb.) 2015, 51, 3645-3648. [CrossRef] [PubMed]

277. Bynoe, M.S.; Viret, C.; Yan, A.; Kim, D.G. Adenosine receptor signaling: A key to opening the blood-brain door. Fluids Barriers CNS 2015, 12, 20. [CrossRef]

278. Carman, A.J.; Mills, J.H.; Krenz, A.; Kim, D.G.; Bynoe, M.S. Adenosine receptor signaling modulates permeability of the blood-brain barrier. J. Neurosci. 2011, 31, 13272-13280. [CrossRef]

279. Gao, X.; Qian, J.; Zheng, S.; Changyi, Y.; Zhang, J.; Ju, S.; Zhu, J.; Li, C. Overcoming the blood-brain barrier for delivering drugs into the brain by using adenosine receptor nanoagonist. ACS Nano 2014, 8, 3678-3689. [CrossRef]

280. Jacobson, K.A.; Gao, Z.G. Adenosine receptors as therapeutic targets. Nat. Rev. Drug Discov. 2006, 5, $247-264$. [CrossRef]

281. Salahuddin, T.S.; Johansson, B.B.; Kalimo, H.; Olsson, Y. Structural changes in the rat brain after carotid infusions of hyperosmolar solutions: A light microscopic and immunohistochemical study. Neuropathol. Appl. Neurobiol. 1988, 14, 467-482. [CrossRef]

282. Bicker, J.; Fortuna, A.; Alves, G.; Falcão, A. Nose-to-brain Delivery of Natural Compounds for the Treatment of Central Nervous System Disorders. Curr. Pharm. Des. 2020, 26, 594-619. [CrossRef]

283. Musumeci, T.; Serapide, M.F.; Pellitteri, R.; Dalpiaz, A.; Ferraro, L.; Dal Magro, R.; Bonaccorso, A.; Carbone, C.; Veiga, F.; Sancini, G.; et al. Oxcarbazepine free or loaded PLGA nanoparticles as effective intranasal approach to control epileptic seizures in rodents. Eur. J. Pharm. Biopharm. 2018, 133, 309-320. [CrossRef] [PubMed]

284. Kumar, N.N.; Lochhead, J.J.; Pizzo, M.E.; Nehra, G.; Boroumand, S.; Greene, G.; Thorne, R.G. Delivery of immunoglobulin $\mathrm{G}$ antibodies to the rat nervous system following intranasal administration: Distribution, dose-response, and mechanisms of delivery. J. Control. Release 2018, 286, 467-484. [CrossRef] [PubMed]

285. Lochhead, J.J.; Kellohen, K.L.; Ronaldson, P.T.; Davis, T.P. Distribution of insulin in trigeminal nerve and brain after intranasal administration. Sci. Rep. 2019, 9, 2621. [CrossRef] [PubMed]

286. Rodriguez, M.; Lapierre, J.; Ojha, C.R.; Kaushik, A.; Batrakova, E.; Kashanchi, F.; Dever, S.M.; Nair, M.; El-Hage, N. Intranasal drug delivery of small interfering RNA targeting Beclin1 encapsulated with polyethylenimine (PEI) in mouse brain to achieve HIV attenuation. Sci. Rep. 2017, 7, 1862. [CrossRef] [PubMed]

287. Belur, L.R.; Temme, A.; Podetz-Pedersen, K.M.; Riedl, M.; Vulchanova, L.; Robinson, N.; Hanson, L.R.; Kozarsky, K.F.; Orchard, P.J.; Frey, W.H., 2nd; et al. Intranasal Adeno-Associated Virus Mediated Gene Delivery and Expression of Human Iduronidase in the Central Nervous System: A Noninvasive and Effective Approach for Prevention of Neurologic Disease in Mucopolysaccharidosis Type I. Hum. Gene Ther. 2017, 28, 576-587. [CrossRef] [PubMed]

288. Aly, A.E.; Harmon, B.; Padegimas, L.; Sesenoglu-Laird, O.; Cooper, M.J.; Yurek, D.M.; Waszczak, B.L. Intranasal delivery of hGDNF plasmid DNA nanoparticles results in long-term and widespread transfection of perivascular cells in rat brain. Nanomedicine 2019, 16, 20-33. [CrossRef]

289. Alarcón-Arís, D.; Recasens, A.; Galofré, M.; Carballo-Carbajal, I.; Zacchi, N.; Ruiz-Bronchal, E.; Pavia-Collado, R.; Chica, R.; Ferrés-Coy, A.; Santos, M.; et al. Selective $\alpha$-Synuclein Knockdown in Monoamine Neurons by Intranasal Oligonucleotide Delivery: Potential Therapy for Parkinson's Disease. Mol. Ther. 2018, 26, 550-567. [CrossRef]

290. Aly, A.E.; Waszczak, B.L. Intranasal gene delivery for treating Parkinson's disease: Overcoming the blood-brain barrier. Expert Opin. Drug Deliv. 2015, 12, 1923-1941. [CrossRef]

291. Kim, I.D.; Shin, J.H.; Kim, S.W.; Choi, S.; Ahn, J.; Han, P.L.; Park, J.S.; Lee, J.K. Intranasal delivery of HMGB1 siRNA confers target gene knockdown and robust neuroprotection in the postischemic brain. Mol. Ther. 2012, 20, 829-839. [CrossRef]

292. Lochhead, J.J.; Thorne, R.G. Intranasal delivery of biologics to the central nervous system. Adv. Drug Deliv. Rev. 2012, 64, 614-628. [CrossRef] 
293. Podolska, K.; Stachurska, A.; Hajdukiewicz, K.; Małecki, M. Gene therapy prospects-intranasal delivery of therapeutic genes. Adv. Clin. Exp. Med. 2012, 21, 525-534. [PubMed]

Publisher's Note: MDPI stays neutral with regard to jurisdictional claims in published maps and institutional affiliations.

(C) 2020 by the authors. Licensee MDPI, Basel, Switzerland. This article is an open access article distributed under the terms and conditions of the Creative Commons Attribution (CC BY) license (http://creativecommons.org/licenses/by/4.0/). 